Electrochemical Technology

Program

Electrochemical Technology

Program

Electrochemical Technology

Program

Electrochemical Technology

Program

Electrochemical Technology

Program

Electrochemical Technology

Program

Electrochemical Technology

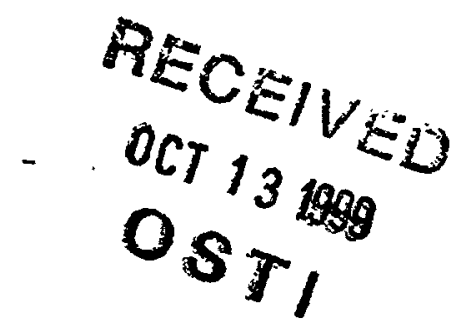

ANL-98/16

Program

Electrochemical Technology

Hydrogen-Fueled Polymer

Program

Electrochemical Technology

Program

Electrochemical Technology Electrolyte Fuel Cell Systems for Transportation

Program

Electrochemical Technology

Program

Electrochemical Technology

Program

Electrochemical Technology

Program

Electrochemical Technology

Program

Electrochemical Technology

Program

Electrochemical Technology

Program

Electrochemical Technology

Program

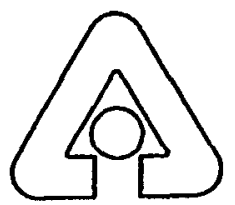

Argonne National Laboratory, Argonne, Illinois 60439

operated by The University of Chicago

for the United States Department of Energy

Chemical Technology

Division

Chemical Technology

Division

Chemical Technology

Division

Chemical Technology

by E. D. Doss, R. Ahluwalia, and R. Kumar 
Argonne National Laboratory, with facilities in the states of Illinois and Idaho, is owned by the United States government, and operated by The University of Chicago under the provisions of a contract with the Department of Energy.

\section{DISCLAIMER}

This report was prepared as an account of work sponsored by an agency of the United States Government. Neither the United States Government nor any agency thereof, nor any of their employees, makes any warranty, express or implied, or assumes any legal liability or responsibility for the accuracy, completeness, or usefulness of any information, apparatus, product, or process disclosed, or represents that its use would not infringe privately owned rights. Reference herein to any specific commercial product, process, or service by trade name, trademark, manufacturer, or otherwise, does not necessarily constitute or imply its endorsement, recommendation, or favoring by the United States Government or any agency thereof. The views and opinions of authors expressed herein do not necessarily state or reflect those of the United States Government or any agency thereof.

Reproduced from the best available copy.

Available to DOE and DOE contractors from the Office of Scientific and Technical Information

P.O. Box 62

Oak Ridge, TN 37831

Prices available from (423) 576-8401

Available to the public from the National Technical Information Service

U.S. Department of Commerce

5285 Port Royal Road

Springfield, VA 22161 


\section{DISCLAIMER}

Portions of this document may be illegible in electronic image products. Images are produced from the best available original document. 


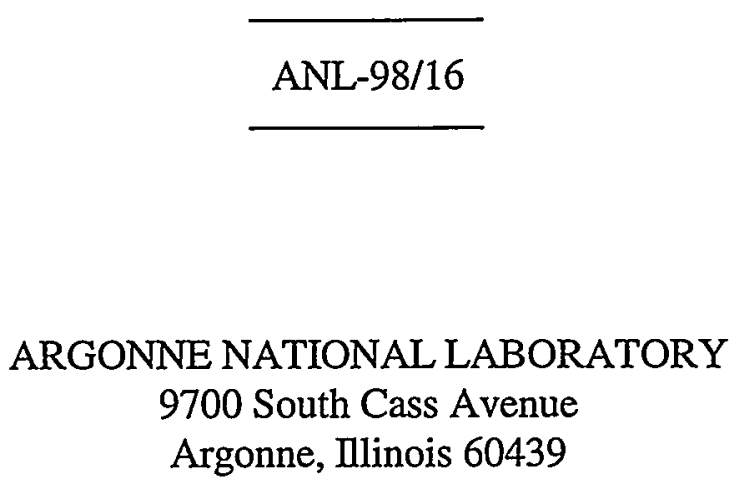

\begin{abstract}
A700 South Cass Avenue
HYDROGEN-FUELED POLYMER ELECTROLYTE FUEL CELL SYSTEMS FOR TRANSPORTATION
\end{abstract}

\author{
by \\ Ezzat Danial Doss, ${ }^{*}$ Rajesh Ahluwalia, ${ }^{*}$ and Romesh Kumar
}

Chemical Technology Division

August 1998

${ }^{*}$ Technology Development Division. 



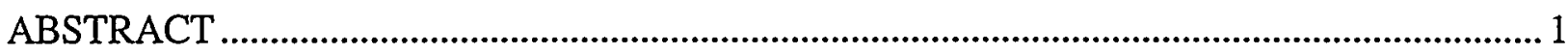

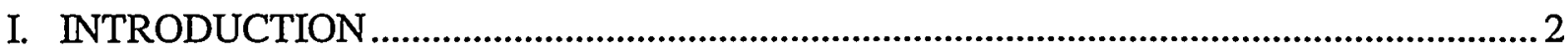

II. SYSTEMS SIMULATION AND MODELING.......................................................................

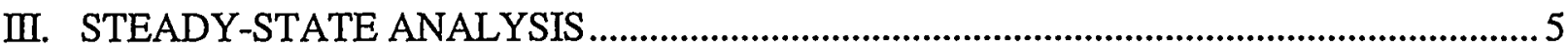

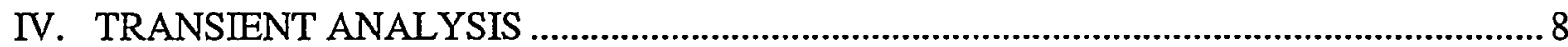

V. APPLICATION TO VEHICLE DRIVING CYCLES .......................................................

A. Analysis for a Conventional Vehicle ……………..................................................... 13

B. Analysis for Near-Term and Future Vehicles ................................................................. 18

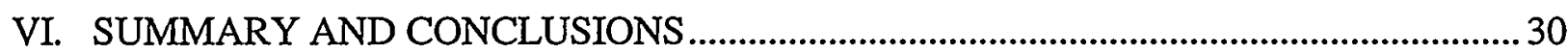

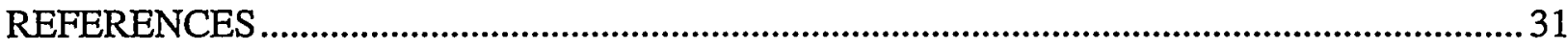

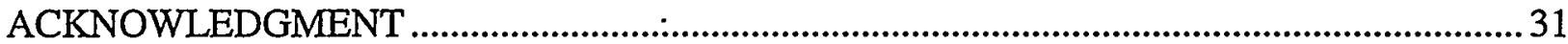




\section{LIST OF FIGURES}

No.

Title

Page

1. Parameters Evaluated for Hydrogen-Fueled Polymer Electrolyte Fuel Cell System .............. 4

2. Compressed Hydrogen-Fueled PEFC System .........................................................................

3. Fuel Cell and Tank Water Temperatures during Startup of a 50-kW Hydrogen-Fueled PEFC System with Coolant Bypass, 10-s Ramp-up Time ......................................................... 8

4. Fuel Cell Current and Voltage during Startup of a 50-kW Hydrogen-Fueled PEFC System with Coolant Bypass, 10-s Ramp-up Time.

5. Fuel Cell Net Power during Startup of a 50-kW Hydrogen-Fueled PEFC System with Coolant Bypass, 10-s Ramp-up Time ...................................................... 10

6. Compressed Hydrogen-Fueled PEFC System with Coolant Flow Splitter ............................ 10

7. Fuel Cell, Coolant, and Tank Water Temperatures during Startup of a 50-kW Hydrogen-Fueled PEFC System with Control of Coolant Temperature, 10-s Ramp-up Time

8. Fuel Cell Current and Voltage during Startup of a 50-kW Hydrogen-Fueled PEFC System with Control of Coolant Temperature, 10-s Ramp-up Time

9. Fuel Cell Net Power during Startup of a 50-kW Hydrogen-Fueled

PEFC System with Control of Coolant Temperature, 10-s Ramp-up Time........................... 12

10. Vehicle Speed versus Time with FUDS Cycle....................................................................... 14

11. Vehicle Power Requirements over the FUDS Cycle .......................................................... 15

12. Fuel Cell and Water-Tank Temperatures over the FUDS Cycle with the 50-kW Hydrogen-Fueled PEFC System - Starting Cold . 15

13. Fuel Cell System Efficiency over the FUDS Cycle with the 50-kW Hydrogen-Fueled PEFC System - Starting Cold .... 16

14. Vehicle-Based Efficiency over the FUDS Cycle with the 50-kW Hydrogen-Fueled PEFC System - Starting Cold 16

15. Hydrogen Consumption over the FUDS Cycle with the 50-kW Hydrogen-Fueled PEFC System - Starting Cold 


\section{LIST OF FIGURES (contd)}

No.

Title

Page

16. Vehicle Speed vs. Time for the Highway Cycle.......................................................................... 19

17. FUDS Cycle Power Requirement for the AIV Sable ...........................................................2

18. Highway Cycle Power Requirement for the AIV Sable ...........................................................2 20

19. FUDS Cycle Power Requirement for the P2000 Vehicle............................................................2

20. Highway Cycle Power Requirement for the P2000 Vehicle .................................................2 21

21. Fuel-Cell and Water-Tank Temperatures for $80-\mathrm{kW}$ PEFC System in the AIV Sable Operated on the Highway Cycle.................................................................................................22

22. Fuel-Cell System Efficiency for 80-kW PEFC System in the AIV Sable Operated on the Highway Cycle ..............................................................................................2 23

23. Vehicle-Based Efficiency for $80-\mathrm{kW}$ PEFC System in the AIV Sable Operated on the Highway Cycle.

24. Hydrogen Consumption for 80-kW PEFC System in the AIV Sable Operated on the Highway Cycle.

25. Fuel Economy of the AIV Sable and the P2000 Vehicles with 80-kW PEFC System under the FUDS, Highway, and Combined Driving Cycles.....................................................2 25

26. Compressed Hydrogen-Fueled PEFC System ........................................................................26

27. Fuel-Cell and Water-Tank Temperatures for 40-kW PEFC System in the AIV Sable Operated on the Highway Cycle.

28. Fuel Cell Efficiency for 40-kW PEFC System in the AIV Sable Operated on the Highway Cycle.

29. Vehicle-Based Efficiency for 40-kW PEFC System in the AIV Sable Operated on the Highway Cycle 28

30. Hydrogen Consumption for 40-kW PEFC System in the AIV Sable Operated on the Highway Cycle 


\section{LIST OF TABLES}

No.

$\underline{\text { Title }}$

$\underline{\text { Page }}$

1. Analysis Results for Steady-State Operating Conditions of $50-\mathrm{kW}$

Hydrogen-Fueled Polymer Electrolyte Fuel Cell System....................................................... 6

2. Analysis Results for the Cold Operation of 50-kW Hydrogen-Fueled

Polymer Electrolyte Fuel Cell System......................................................................................

3. Simulation Parameters for a Mid-size 1995 Chrysler Sedan................................................... 13

4. Summary of Results for Four FUDS Cases...................................................................... 18

5. Simulation Parameters for the AIV Sable and P2000 Vehicles ............................................ 18

6. Performance Summary of the 80-kW AIV Sable and P2000 Vehicles with

Constant and Variable Compressor and Expander Efficiencies.............................................25

7. Performance Summary of AIV Sable and P2000 Vehicles with 40-kW PEFC System with Constant Compressor and Expander Efficiencies 


\title{
HYDROGEN-FUELED POLYMER ELECTROLYTE FUEL CELL SYSTEMS FOR TRANSPORTATION
}

\author{
Ezzat Danial Doss, Rajesh Ahluwalia, and Romesh Kumar
}

\begin{abstract}
The performance of a polymer electrolyte fuel cell (PEFC) system that is fueled directly by hydrogen has been evaluated for transportation vehicles. The performance was simulated using a systems analysis code and a vehicle analysis code.

The results indicate that, at the design point for a 50-kW PEFC system, the system efficiency is above $50 \%$. The efficiency improves at partial load and approaches $60 \%$ at $40 \%$ load, as the fuel cell operating point moves to lower current densities on the voltage-current characteristic curve. At much lower loads, the system efficiency drops because of the deterioration in the performance of the compressor, expander, and, eventually, the fuel cell. The results also indicate that the PEFC system can start rapidly from ambient temperatures. Depending on the specific weight of the fuel cell $(1.6 \mathrm{~kg} / \mathrm{kW}$ in this case), the system takes up to $180 \mathrm{~s}$ to reach its design operating conditions.

The PEFC system has been evaluated for three mid-size vehicles: the 1995 Chrysler Sedan, the near-term Ford AIV (Aluminum Intensive Vehicle) Sable, and the future P2000 vehicle. The results show that the PEFC system can meet the demands of the Federal Urban Driving Schedule and the Highway driving cycles, for both warm and cold start-up conditions. The results also indicate that the P2000 vehicle can meet the fuel economy goal of 80 miles per gallon of gasoline (equivalent).
\end{abstract}




\section{INTRODUCTION}

Over the past few years, fuel cells, especially polymer electrolyte fuel cells (PEFC), have shown promise of becoming a viable alternative to today's internal combustion engines for transportation applications. The PEFC is powered by a hydrogen-rich gas stream. This fuel can be provided either by use of hydrogen fuel directly or by reforming of hydrocarbon fuels such as natural gas, methanol, or gasoline. This report is limited to the study of the performance of direct-hydrogen-fueled PEFC systems. Work is in progress to investigate the performance of other systems and will be the subject of future reports.

Argonne National Laboratory (ANL) has developed a computer simulation capability to study the performance of different advanced power generation concepts for terrestrial and space applications. In Section II, the general approach to systems simulation is discussed, with particular emphasis on PEFC systems. In Section III, this approach is used to study the performance of a stand-alone hydrogen-fueled PEFC system during steady-state operating conditions at the design point and partial loads. The performance of the system is determined under cold start-up conditions, where the temperature of all the system components, including the fuel cell, is $300 \mathrm{~K}$.

In Section IV, transient analysis is used to examine the performance of this system under cold and warm start-up conditions. The start-up procedure was simulated over ramp-up times of 10,5 , and $1 \mathrm{~s}$.

Finally, in Section V, the PEFC system is evaluated for three mid-size vehicles: the 1995 Chrysler sedan, the near-term Ford AIV (Aluminum Intensive Vehicle) Sable, and the future P2000 vehicle. The evaluation is performed over two driving cycles, the Federal Urban Driving Schedule (FUDS) and the Highway cycle, and for fuel cells having power capabilities of 40 to $100 \mathrm{~kW}$. 


\section{SYSTEMS SIMULATION AND MODELING}

Computer modeling of the fuel-cell system components is an ongoing activity at Argonne National Laboratory. The purpose of this work is to improve existing models and to incorporate new models or features to respond to special needs. Models of the system components consist of data structures, as well as the associated set of mathematical functions. The output of the model of a given component is a function only of the model parameters and input flows (and time for dynamic simulations). Each model maintains mass and energy balances.

The systems simulation code is capable of handling recycle flows and of performing optimization studies under various physical constraints. Iterative tasks are used, as needed, to handle parametric sweeps, system constraints, optimizations, and dynamic time integrations. In performing the system simulations, thermodynamic data and physical-property calculation utilities for chemical kinetics and multiphase equilibria are used. The various thermodynamic property routines available include the water-steam property code, the Lee-Kesler single-species equation of state, the gas-phase chemical equilibrium code (minimization of Gibbs free energy subject to atom balance constraints), and the multiphase chemical equilibrium code. Details of the system code are provided in Ref. 1, and the dynamic flow system simulation is described in Ref. 2.

The ultimate goal of the systems simulation is to provide reliable predictions for the performance of the PEFC system. This includes its performance at the design point, performance under partial-load operating conditions for warm and cold start, and transient behavior. Also included is the performance of current and future vehicles operating with such a system over typical driving cycles.

Figure 1 shows schematically the significant inputs and outputs for the hydrogen-fueled PEFC system. Look-up tables can be derived from the results obtained from the systems simulation and can be incorporated into other vehicle models, as needed. 


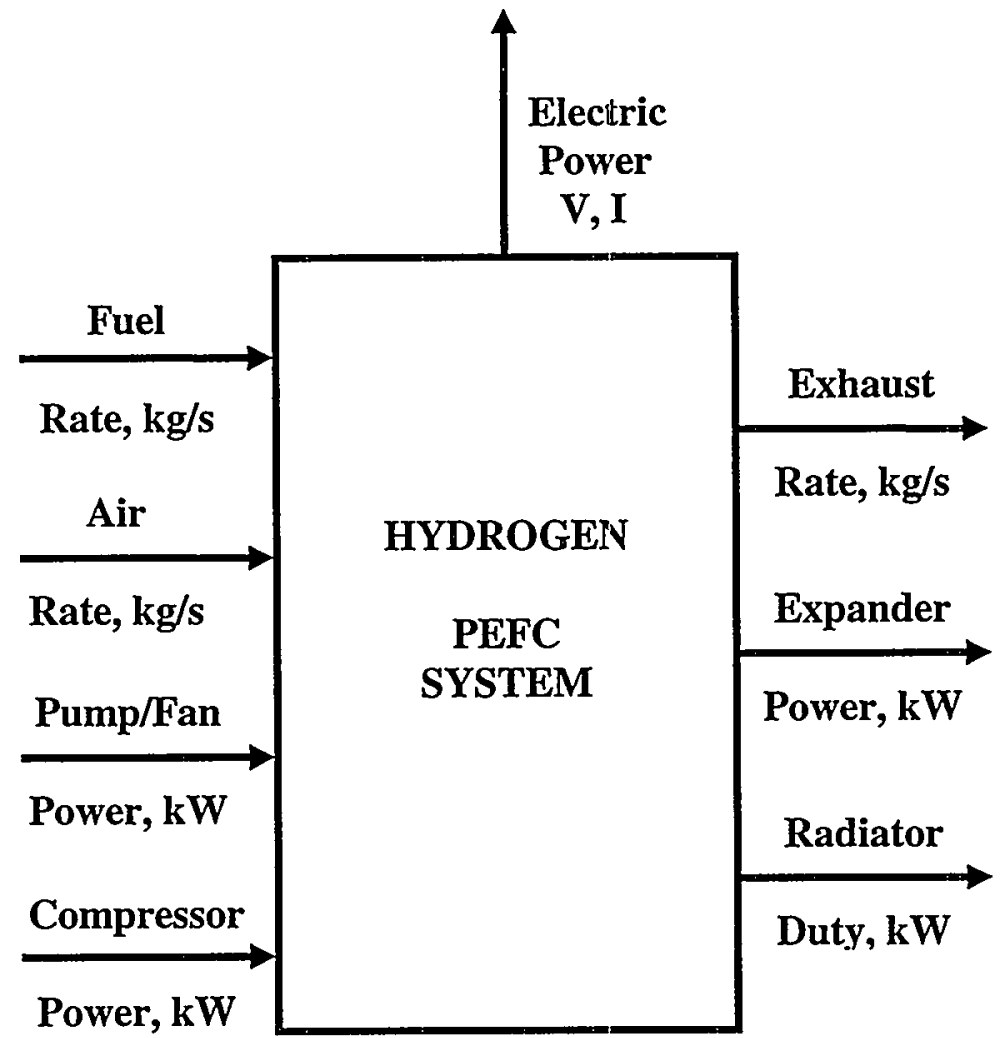

Fig. 1. Parameters Evaluated for Hydrogen-Fueled Polymer Electrolyte Fuel Cell System 


\section{STEADY-STATE ANALYSIS}

A parametric study has been conducted to determine the performance of a $50-\mathrm{kW}$ (net power) hydrogen-fueled PEFC system at the design point and partial-load operating conditions. Figure 2 is a schematic of the $50-\mathrm{kW}$ system. It consists of a fuel reservoir supplying hydrogen at $3 \mathrm{~atm}$ to the anode side of the PEFC. A two-stage inter-cooled compressor supplies the oxidant air to the cathode side of the PEFC. Downstream of the PEFC, a gas turbine is used to recover the pressure energy in the spent cathode gas. A water tank, pump, and air-cooled radiator comprise the coolant circuit. For the fuel cell stack, the voltage-current characteristic ("polarization curve") is expressed as a function of pressure, temperature, and the fuel and oxidant stoichiometries. The experimental results given in Refs. 3 and 4 are curve fitted and used in the analysis. The input data include results for cell temperatures as low as $293 \mathrm{~K}\left(20^{\circ} \mathrm{C}\right)$. The average cell current density was taken to be $0.7 \mathrm{~A} / \mathrm{cm}^{2}$ at the design point. The fuel cell active area and the heat-exchanger surface areas were calculated and kept constant for simulations in the partial-load mode. The pressures, temperatures, and mass flow rates for the various streams at selected points are shown in Fig. 2.

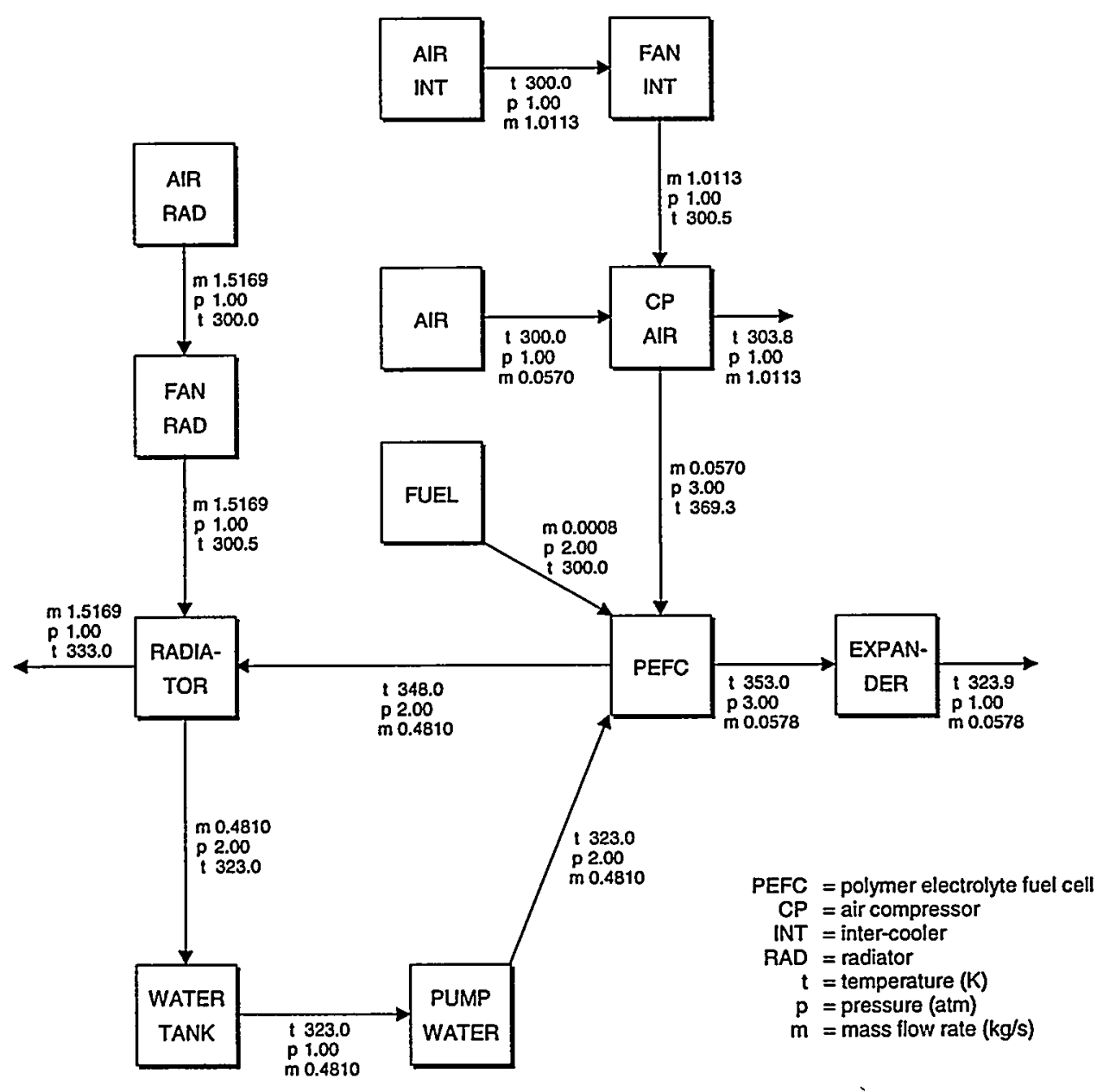

Fig. 2. Compressed Hydrogen-Fueled PEFC System $(50 \mathrm{~kW})$ 
For partial-load operations, the compressor, expander, and the fan efficiencies were treated as a function of the ratio of the mass flow rates through the unit, relative to their design values. At the design point, the compressor and expander efficiencies were assumed to be $80 \%$. At partial loads, the efficiency was varied by a factor of 1.0 for the 0.6 ratio and above, 0.9 at the 0.4 ratio, 0.6 at the 0.2 ratio, and 0.3 at the 0.1 ratio. The coolant water flow rate and the air flow rate through the compressor inter-cooler were kept constant, while the air flow rate through the radiator was varied to achieve steady-state conditions for the heat exchangers and the fuel cell. The fuel utilization was kept constant at $100 \%$ for all conditions.

Table 1 presents the computed results for steady-state operating conditions at $100 \%, 80 \%$, $60 \%, 40 \%, 20 \%, 15 \%, 10 \%$, and $0 \%$ of the design power level. The fuel and air consumption decrease disproportionately at partial load. The system efficiency improves at partial load and approaches $60 \%$ at $40 \%$ load. The improvement results from the fuel cell operating at higher voltages on the V-I curve. At much lower loads, the system efficiency drops because of the deterioration in the performance of the compressor and the expander. The coolant temperature

Table 1. Analysis Results for Steady-State Operating Conditions of 50-kW Hydrogen-Fueled Polymer Electrolyte Fuel Cell System

\begin{tabular}{|c|c|c|c|c|c|c|c|c|c|c|c|}
\hline $\begin{array}{c}\text { Net } \\
\text { Power, } \\
\mathrm{kW}\end{array}$ & $\begin{array}{c}\text { Gross } \\
\text { Power, } \\
\mathrm{kW}\end{array}$ & $\begin{array}{c}\text { Stack } \\
\text { Volts, } \\
\mathrm{V}\end{array}$ & $\begin{array}{c}\text { Stack } \\
\text { Current, }\end{array}$ & $\begin{array}{c}\text { System } \\
\text { Eff., } \\
\%\end{array}$ & $\begin{array}{c}\text { Fuel } \\
\text { Flow, } \\
\mathrm{g} / \mathrm{s}\end{array}$ & $\begin{array}{c}\text { Air } \\
\text { Flow, } \\
\mathrm{g} / \mathrm{s}\end{array}$ & $\begin{array}{c}\text { Exhaust } \\
\text { Flow, } \\
\mathrm{g} / \mathrm{s}\end{array}$ & $\begin{array}{c}\text { Pump/Fan } \\
\text { Power, } \\
\mathrm{kW}\end{array}$ & $\begin{array}{c}\text { Compres- } \\
\text { sor Power, } \\
\mathrm{kW}\end{array}$ & $\begin{array}{c}\text { Expander } \\
\text { Power, } \\
\mathrm{kW}\end{array}$ & $\begin{array}{c}\text { Radiator } \\
\text { Duty, } \\
\mathrm{kW}\end{array}$ \\
\hline 50 & 53.89 & 100.0 & 538.5 & 50.8 & 0.821 & 57.0 & 57.83 & 1.443 & 7.44 & 4.99 & 50.29 \\
\hline 40 & 42.79 & 110.0 & 389.1 & 56.2 & 0.594 & 41.2 & 41.79 & 1.020 & 5.37 & 3.60 & 32.50 \\
\hline 30 & 32.50 & 117.2 & 277.3 & 59.1 & 0.423 & 29.4 & 29.78 & 0.942 & 4.01 & 2.45 & 21.25 \\
\hline 20 & 22.66 & 123.5 & 183.5 & 59.6 & 0.280 & 19.4 & 19.70 & 0.880 & 3.15 & 1.37 & 13.16 \\
\hline 10 & 12.72 & 130.0 & 97.9 & 55.9 & 0.149 & 10.4 & 10.51 & 0.811 & 2.42 & 0.51 & 6.77 \\
\hline 7.5 & 10.14 & 131.8 & 76.9 & 53.3 & 0.117 & 8.2 & 8.26 & 0.787 & 2.21 & 0.34 & 5.34 \\
\hline 5 & 7.45 & 134.0 & 55.6 & 49.2 & 0.085 & 5.9 & 5.97 & 0.757 & 1.90 & 0.21 & 3.90 \\
\hline 0 & 1.09 & 143.3 & 7.6 & 0 & 0.012 & 0.8 & 0.82 & 0.647 & 0.46 & 0.02 & 0.59 \\
\hline
\end{tabular}

(not shown in Table 1) gradually increases from $323 \mathrm{~K}\left(50^{\circ} \mathrm{C}\right)$ at the design point to about $353 \mathrm{~K}$ $\left(80^{\circ} \mathrm{C}\right)$ near zero load, thus approaching the fuel cell operating temperature. The results also indicate that sufficient water is formed from electrochemical oxidation of hydrogen at $100 \%$ fuel utilization and 3-atm pressure that a humidifier is not required to maintain the PEFC membrane wet. Therefore, the system design has no condenser in this system.

Another parametric study was performed for system start-up, where all the system components, including the fuel cell stack, were assumed to start from ambient conditions 
$(\mathrm{T}=300 \mathrm{~K})$. In this study, the design parameters for the heat-exchanger surface areas and the fuel cell area were kept constant for partial-load conditions, and the fuel utilization was also kept constant at $100 \%$. However, for the case of cold start-up, no air or coolant flow was allowed to pass through the radiator, as the coolant flow bypassed the radiator. The results are presented in Table 2 and indicate that the fuel cell system cannot deliver $50 \mathrm{~kW}$ at start-up. The predicted maximum power that can be produced is $38 \mathrm{~kW}$, with a corresponding efficiency of $36.3 \%$. The reason for these low values is the starting temperature of the fuel cell, which affects the polarization curve. For the same reason, the system efficiencies are lower in Table 2 compared with Table 1 for the fully warmed-up operation.

Table 2. Analysis Results for the Cold Operation of 50-kW Hydrogen-Fueled Polymer Electrolyte Fuel Cell System

\begin{tabular}{|c|c|c|c|c|c|c|c|c|c|c|c|}
\hline $\begin{array}{c}\text { Net } \\
\text { Power, } \\
\mathrm{kW}\end{array}$ & $\begin{array}{c}\text { Gross } \\
\text { Power, } \\
\mathrm{kW}\end{array}$ & $\begin{array}{c}\text { Stack } \\
\text { Volts, } \\
\mathrm{V}\end{array}$ & $\begin{array}{c}\text { Current, } \\
\mathrm{A}\end{array}$ & $\begin{array}{c}\text { System } \\
\text { Eff., } \\
\%\end{array}$ & $\begin{array}{c}\text { Fuel } \\
\text { Flow, } \\
\mathrm{g} / \mathrm{s}\end{array}$ & $\begin{array}{c}\text { Air } \\
\text { Flow, } \\
\mathrm{g} / \mathrm{s}\end{array}$ & $\begin{array}{c}\text { Exhaust } \\
\text { Flow, } \\
\mathrm{g} / \mathrm{s}\end{array}$ & $\begin{array}{c}\text { Pump/Fan } \\
\text { Power, } \\
\mathrm{kW}\end{array}$ & $\begin{array}{c}\text { Compres- } \\
\text { sor Power, } \\
\mathrm{kW}\end{array}$ & $\begin{array}{c}\text { Expander } \\
\text { Power, } \\
\mathrm{kW}\end{array}$ & $\begin{array}{c}\text { Radiator } \\
\text { Duty, } \\
\mathrm{kW}\end{array}$ \\
\hline 37.7 & 42.57 & 74.68 & 570.0 & 36.3 & 0.869 & 60.4 & 61.22 & 0.616 & 7.87 & 3.79 & 0.0 \\
\hline 30 & 32.96 & 100.6 & 327.7 & 50.0 & 0.500 & 34.7 & 35.24 & 0.616 & 4.52 & 2.18 & 0.0 \\
\hline 20 & 22.73 & 114.3 & 198.8 & 55.5 & 0.303 & 21.1 & 21.36 & 0.616 & 3.24 & 1.10 & 0.0 \\
\hline 10 & 12.68 & 125.6 & 100.9 & 54.2 & 0.154 & 10.7 & 10.84 & 0.616 & 2.44 & 0.38 & 0.0 \\
\hline 7.5 & 10.08 & 128.5 & 78.5 & 52.3 & 0.120 & 8.31 & 8.43 & 0.616 & 2.22 & 0.25 & 0.0 \\
\hline 5 & 7.37 & 131.7 & 56.0 & 48.8 & 0.085 & 5.93 & 6.01 & 0.616 & 1.91 & 0.15 & 0.0 \\
\hline 0 & 1.05 & 143.1 & 7.4 & 0 & 0.011 & 0.78 & 0.79 & 0.616 & 0.45 & 0.01 & 0.0 \\
\hline
\end{tabular}




\section{TRANSIENT ANALYSIS}

A transient analysis was carried out for the $50-\mathrm{kW}$ hydrogen-fueled PEFC system (Fig. 2). The objective of this aspect of the study was to examine the system performance as it was started up from ambient conditions $\left(300 \mathrm{~K}, 27^{\circ} \mathrm{C}\right)$. The water tank model was modified to handle the dynamic mode of operation. The temperature and the mass of the coolant inside the tank. were allowed to vary with time, and the temperature of the coolant flowing into the tank could be different from that inside the tank. In this case, the initial mass and the initial coolant temperature inside the tank were specified.

The fuel cell model was also modified to allow for the computation of the transient change of the fuel cell temperature. The fuel cell is treated as a control volume with specified values for the weight, surface area, heat transfer coefficient, and specific heat. Other dynamic models used in the analysis are described in detail in Ref. 2.

The start-up procedure for the conditions shown in Fig. 2 was simulated over "ramp-up times" of 10,5 , and $1 \mathrm{~s}$. The flow rates of the fuel $\left(\mathrm{H}_{2}\right)$, compressor air, fan air, and cooling water were increased linearly to their steady-state values during the start-up time. The computations were carried out for $800 \mathrm{~s}$. Figures 3 through 5 give the performance results computed for the ramp-up time of $10 \mathrm{~s}$.

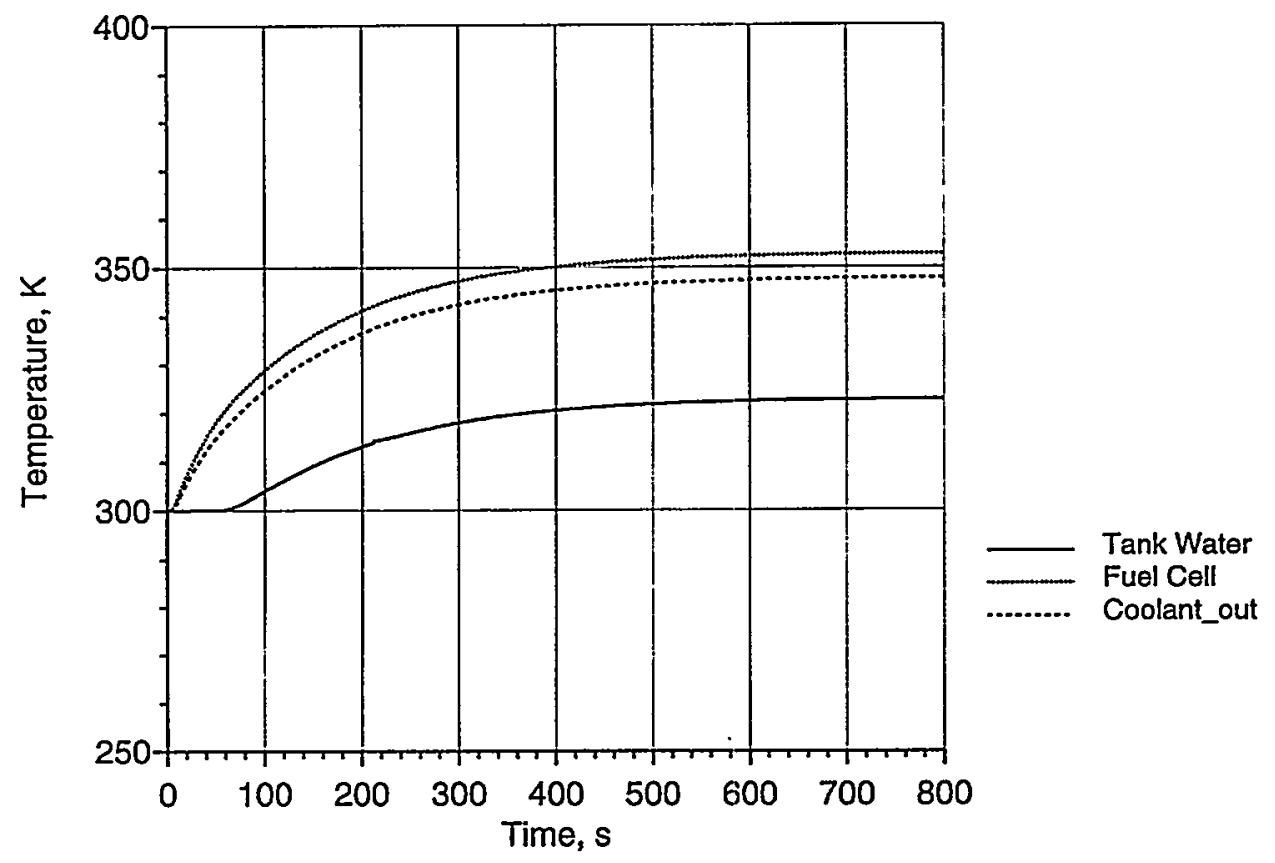

Fig. 3. Fuel Cell and Tank Water Temperatures during Startup of a 50-kW Hydrogen-Fueled PEFC System with Coolant Bypass, 10-s Ramp-up Time

Figure 3 shows the time variation of the fuel cell temperature, the coolant temperature at the exit of the PEFC, and the tank water temperature. The results indicate a smooth rise in the 
temperatures with time for the fuel cell and the cooling water out of the cell. The tank water temperature remained relatively close to the ambient temperature for about $50 \mathrm{~s}$ before starting to increase smoothly. In general, the results show that it takes about $600 \mathrm{~s}$ for the fuel cell stack to reach its normal operating temperature of $353 \mathrm{~K}\left(80^{\circ} \mathrm{C}\right)$.

Figure 4 presents the time variation of the cell voltage and current density. The variation during the ramp-up time of $10 \mathrm{~s}$ is due mainly to starting the system near open-circuit conditions with high cell voltage and very little or no current. Once the design flow rates were achieved, the cell current density reached its steady-state value, while the voltage gradually increased with time toward its design value, as the cell temperature increased.

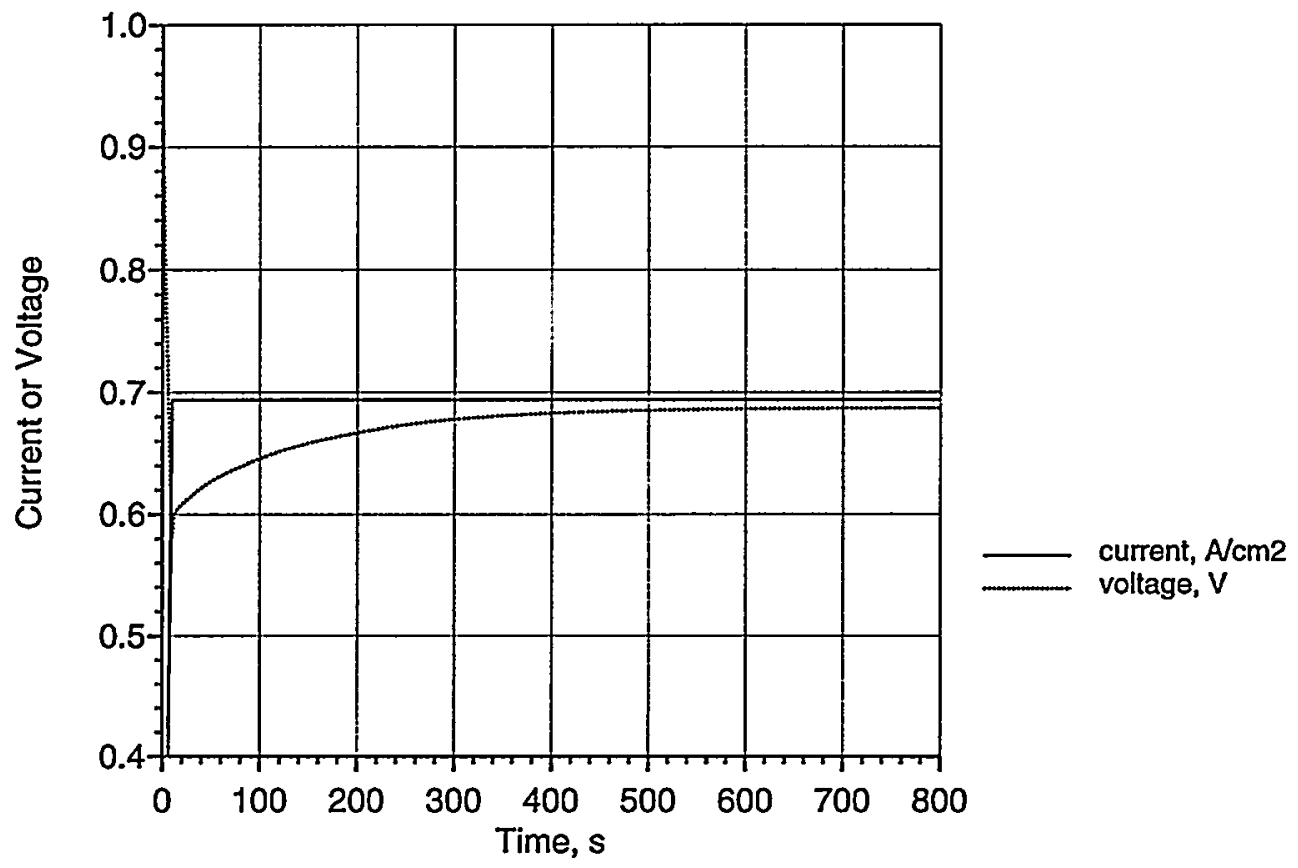

Fig. 4. Fuel Cell Current and Voltage during Startup of a 50-kW HydrogenFueled PEFC System with Coolant Bypass, 10-s Ramp-up Time

Figure 5 shows the variation of the fuel-cell net power with time. The fuel cell responded almost instantly to the increase in the flow rates of fuel and air during the $10 \mathrm{~s}$ ramp-up of the flow. The system produced about $42 \mathrm{~kW}(84 \%$ of the steady-state value) at the end of the rampup time. The power then increased slowly with time over the next several minutes toward its design value of $50 \mathrm{~kW}$. The relatively long time needed for the system to warm up is due to allowing the coolant water to flow through the radiator, even though the system components were far below their normal operating temperatures.

A modified version of the PEFC system in Fig. 2 yielded a quicker warm-up and, thus, a faster approach to the design power. In this modified system, shown in Fig. 6, the coolant bypassed the radiator until its temperature reached $348 \mathrm{~K}\left(75^{\circ} \mathrm{C}\right)$. Figures 7 through 9 present the calculated performance of the system with a 10-s ramp-up time. In this case, the warm-up time 


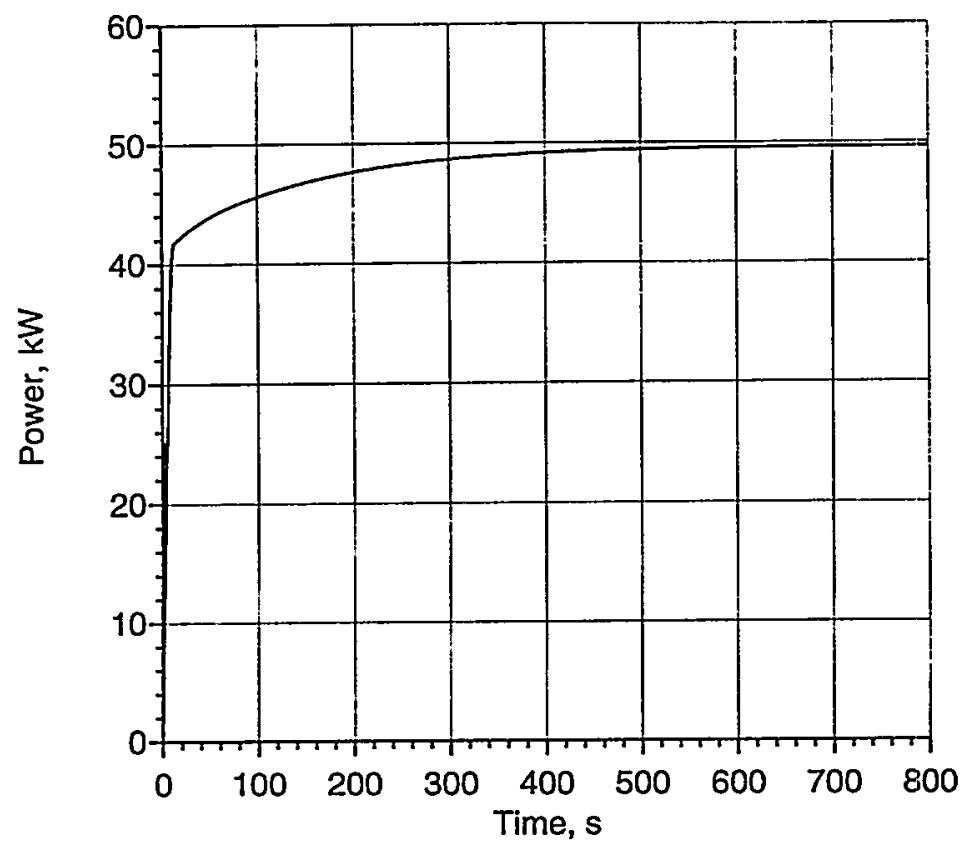

Fig. 5.

Fuel Cell Net Power during Startup of a 50-kW Hydrogen-Fueled PEFC System with Coolant Bypass, 10-s Ramp-up Time

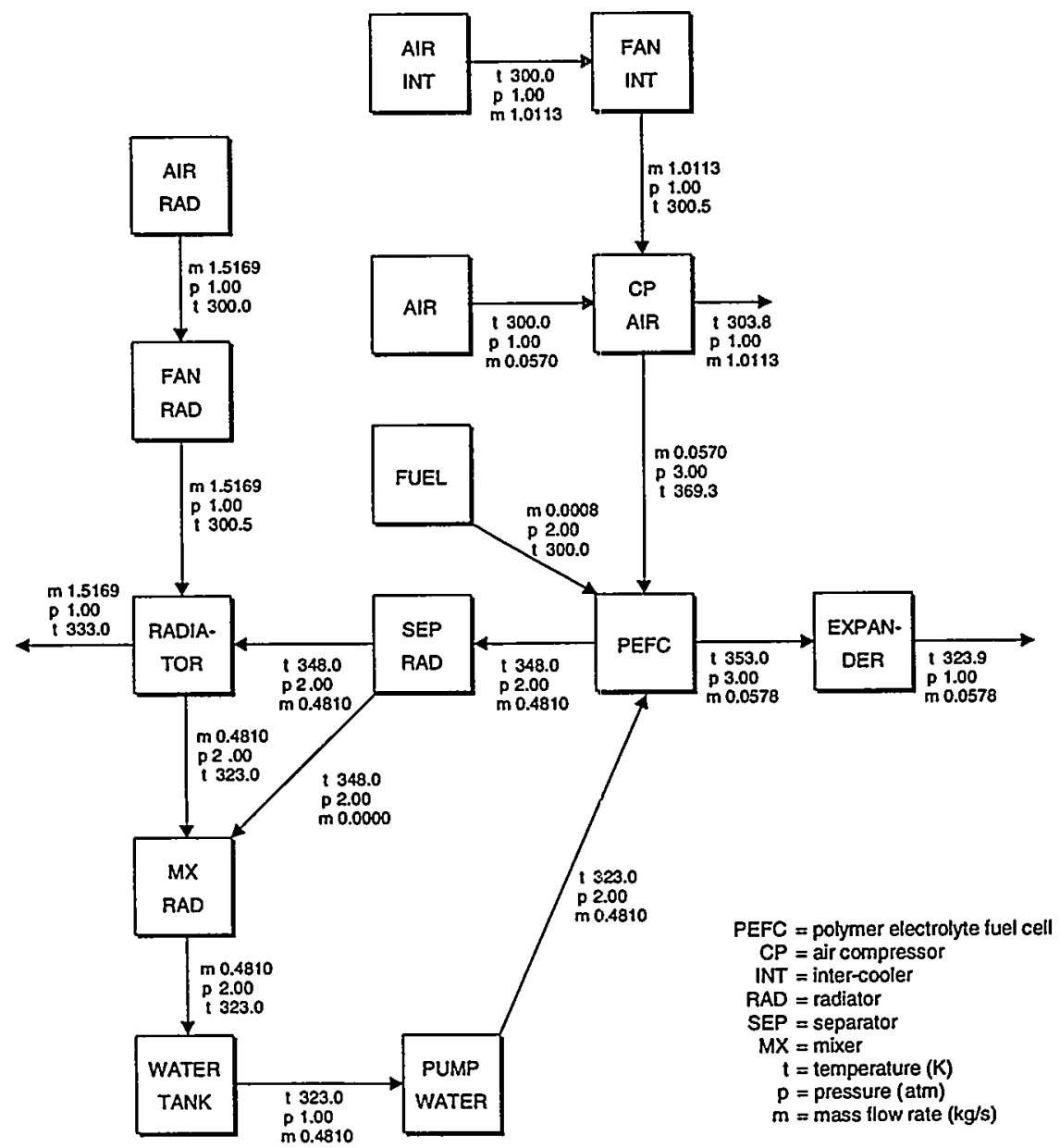

Fig. 6. Compressed Hydrogen-Fueled PEFC System (50 kW) with Coolant Flow Splitter 


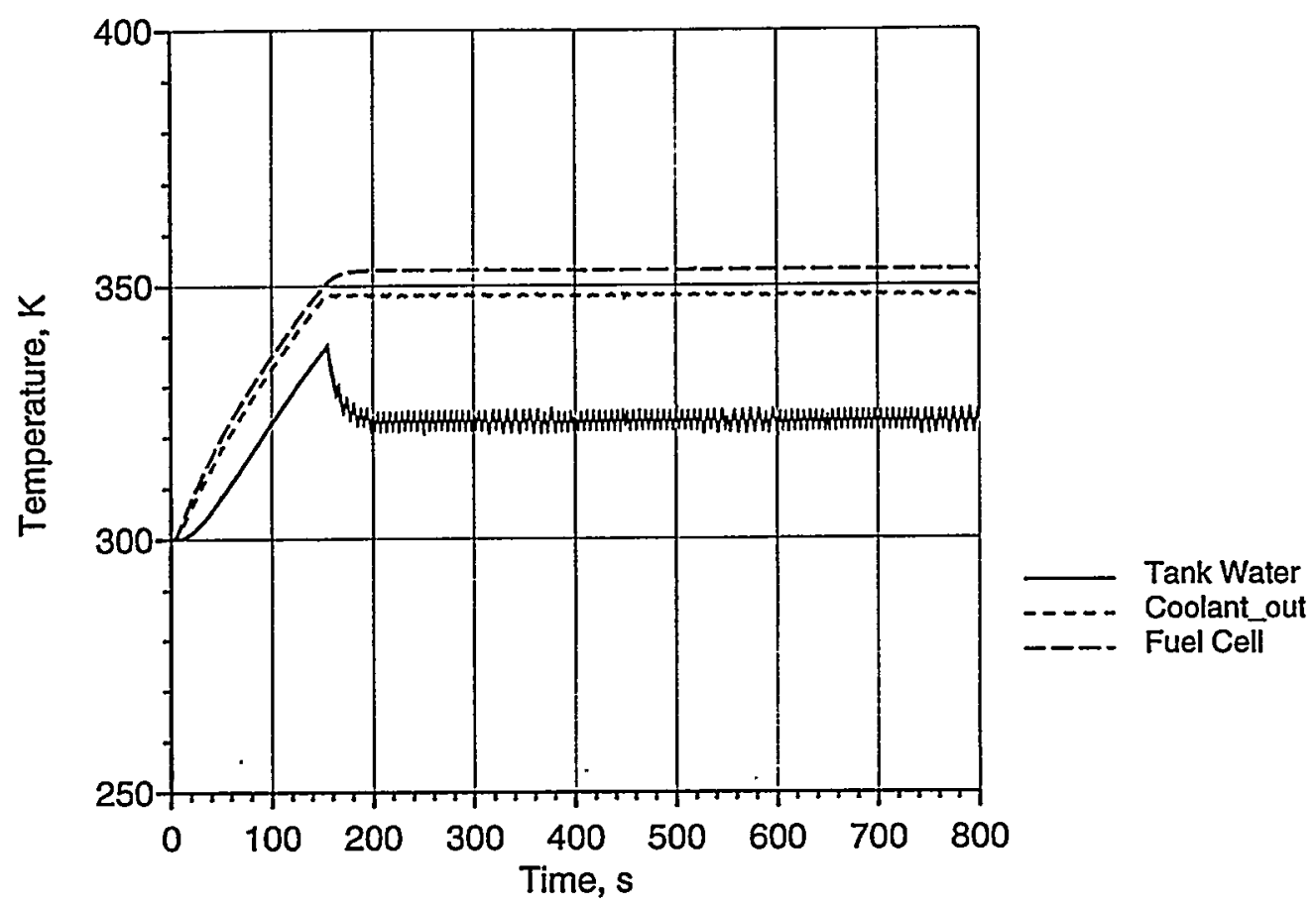

Fig. 7. Fuel Cell, Coolant, and Tank Water Temperatures during Startup of a 50-kW Hydrogen-Fueled PEFC System with Control of Coolant Temperature, 10-s Ramp-up Time

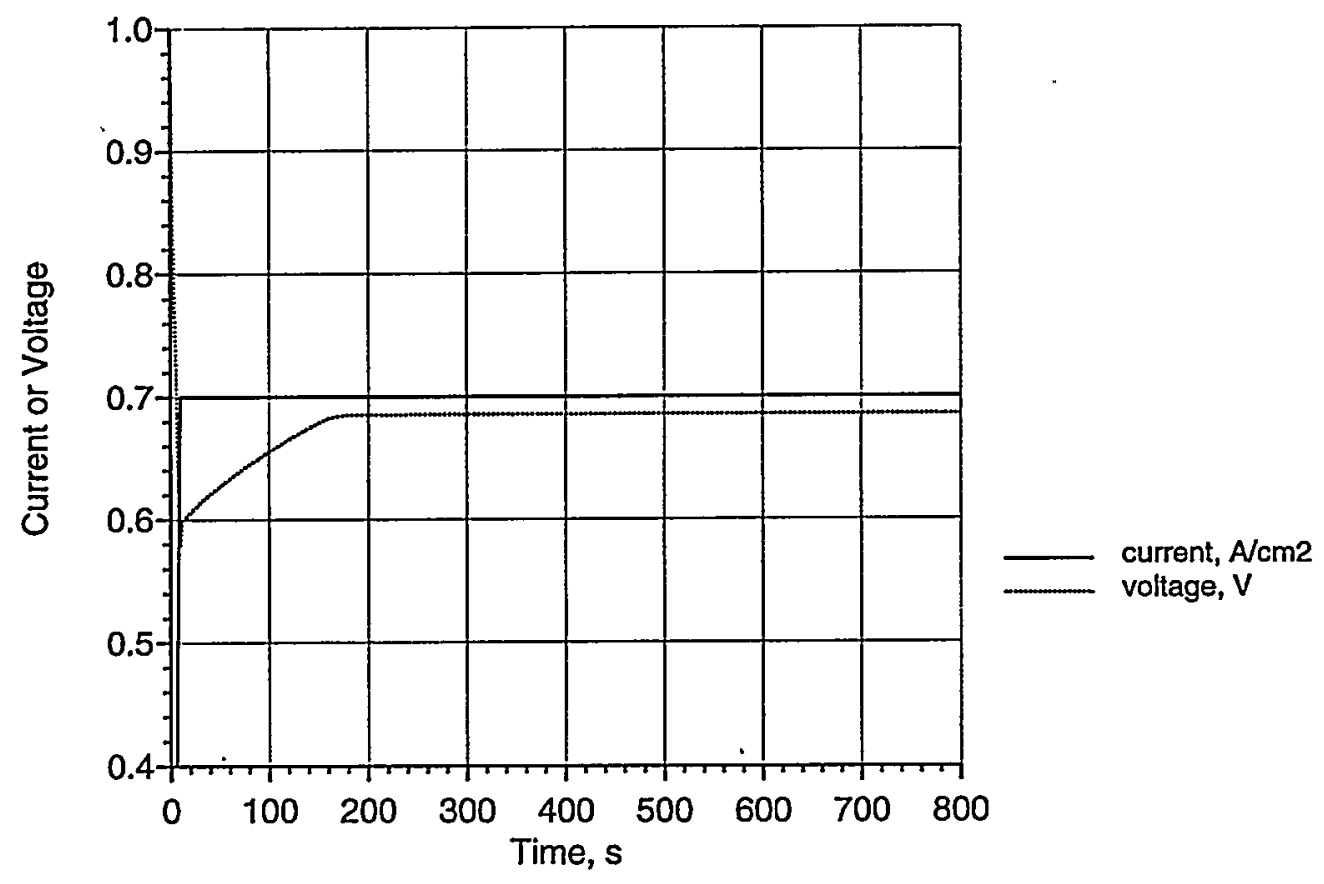

Fig. 8. Fuel Cell Current and Voltage during Startup of a 50-kW Hydrogen-Fueled PEFC System with Control of Coolant Temperature, 10-s Ramp-up Time 


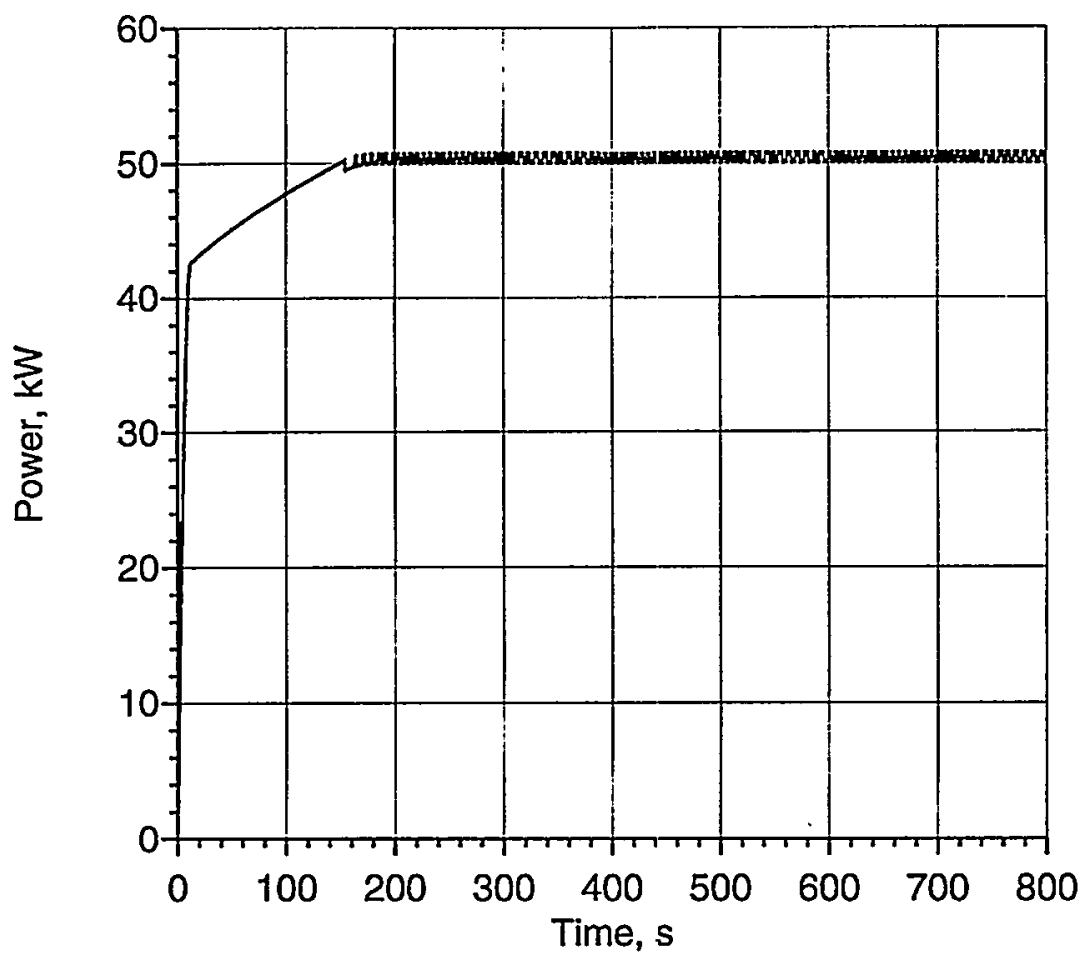

Fig. 9. Fuel Cell Net Power during Startup of a 50-kW Hydrogen-Fueled PEFC System with Control of Coolant Temperature, 10-s Ramp-up Time

for the system was reduced to $180 \mathrm{~s}$. At this time, the fuel cell temperature reached its design value, and the coolant was allowed to flow through the radiator. This process was repeated, leading to the see-saw variation of the coolant temperature inside the water tank, as shown in Fig. 7. These results simulate the behavior of a thermostat control valve for a radiator in a conventional vehicle, where the valve is opened only when the coolant temperature reaches a specified higher temperature, in reference to the ambient temperature.

Similar results were obtained for reduced ramp-up times of 5 and $1 \mathrm{~s}$. In sum, the results indicate that the fuel cell and the system respond almost immediately to the increase in flow rates, and that the fuel cell produces more than $80 \%$ of its nominal power by the end of the ramp-up time.

The main conclusion of this transient analysis is that the hydrogen-fueled PEFC system can start rapidly, within seconds, from ambient conditions. However, the warm-up time for this system is about $180 \mathrm{~s}$. During this period, it is important for the coolant to bypass the radiator until the coolant temperature approaches the design operating temperature for the fuel cell. 


\section{APPLICATION TO VEHICLE DRIVING CYCLES}

\section{A. Analysis for a Conventional Vehicle}

The systems simulation model was used to examine the performance of a 1995 mid-size Chrysler Sedan (LH model) powered by a stand-alone fuel cell system. The simulation parameters-for this vehicle that were used in the analysis are shown in Table 3 (from Ref. 5, Table 1-1, pp. 1-4).

Table 3. Simulation Parameters for a Mid-size 1995 Chrysler Sedan

\begin{tabular}{|l|c|}
\hline Performance Test Weight, $\mathrm{kg}$ & 1770 \\
\hline Frontal Area, $\mathrm{m}^{2}$ & 2.20 \\
\hline Drag Coefficient & 0.35 \\
\hline Coefficient for Rolling Resistance & 0.0076 \\
\hline Wheel Radius, $\mathrm{mm}$ & 325 \\
\hline Auxiliary Power, $\mathrm{kW}$ (constant) & 2.3 \\
\hline
\end{tabular}

The variation of vehicle speed over the FUDS driving cycle is presented in Fig. 10. The total distance covered in the course of this cycle is 7.4 miles over $1371 \mathrm{~s}$. The power required to operate the vehicle was computed on the basis of the vehicle's speed and its simulation parameters (Table 3). The maximum power requirement for this vehicle was calculated to be $47.4 \mathrm{~kW}$. Therefore, a 50-kW (net) fuel cell system was used in the analysis to meet the FUDS cycle power requirements, including the $2.3-\mathrm{kW}$ auxiliary loads.

The following four cases were investigated:

Case 1: Starting the FUDS cycle cold, where all system components are at the ambient temperature of $300 \mathrm{~K}$.

Case 2: Starting the FUDS cycle immediately after the end of the first FUDS cycle (Case 1), with the system partially warmed up.

Case 3: Starting the FUDS cycles from the system's design point, where the cell temperature is $353 \mathrm{~K}\left(80^{\circ} \mathrm{C}\right)$ and the ambient temperature is $300 \mathrm{~K}$.

Case 4: Starting the FUDS cycle cold $(300 \mathrm{~K})$, with a $100-\mathrm{kW}$ fuel cell system (no increase in vehicle weight). This system meets the further demand for accelerating the vehicle from 0 to $60 \mathrm{mph}$ in $12 \mathrm{~s}$, as specified by the car manufacturers. 


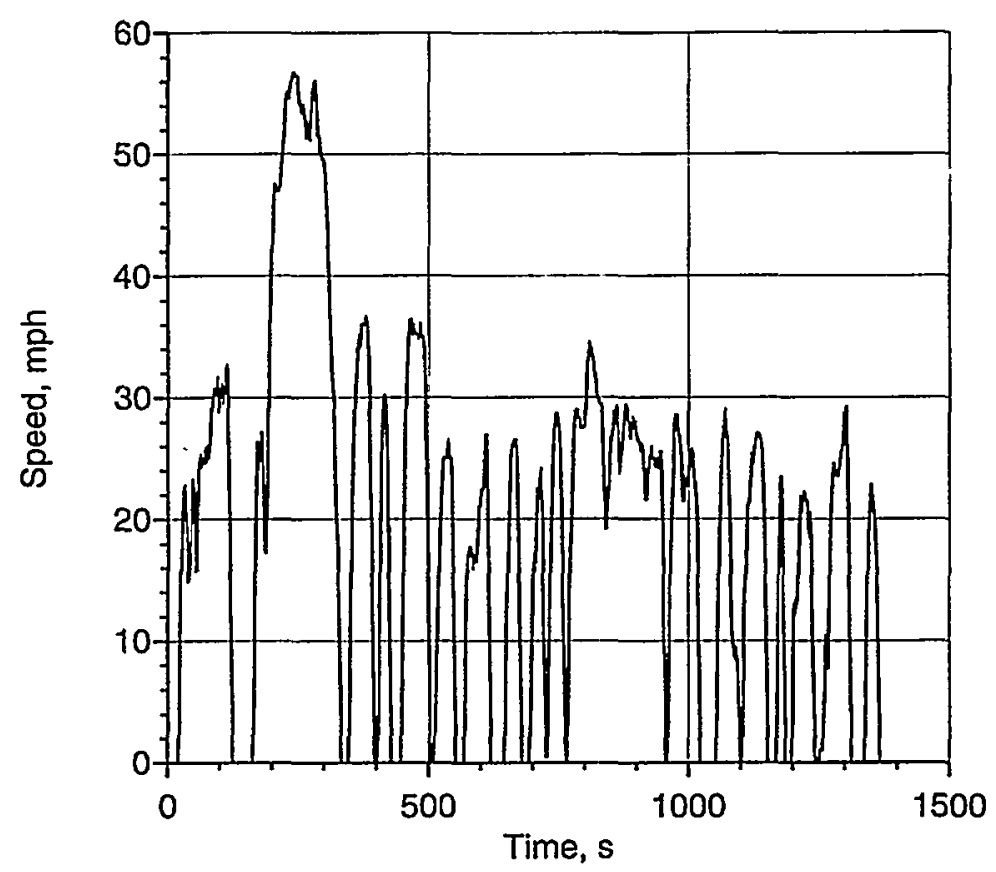

Fig. 10. Vehicle Speed versus Time with FUDS Cycle

The ramp-up time for these cases was taken to be one second. The fan, expander, and compressor efficiencies were kept constant at 0.8 . Figures 11 through 15 show the results of the simulation for Case 1. Figure 11 shows the instantaneous and the average (from the beginning of the cycle) power requirement over the FUDS cycle. The maximum power required is $47.4 \mathrm{~kW}$ (at about $200 \mathrm{~s}$ into the cycle), while the maximum average power requirement is less than $12 \mathrm{~kW}$ (at about $280 \mathrm{~s}$ into the cycle). The average power required over the entire FUDS cycle, including the $2.3 \mathrm{~kW}$ auxiliary load, is approximately $8 \mathrm{~kW}$.

The time variations of the fuel-cell and water-tank temperatures during the FUDS cycle are shown in Fig. 12. The temperatures rose most rapidly during the period from 200 to $300 \mathrm{~s}$. This was the time period when the power demand from the system was the highest. It should be noted, however, that over this cycle, the fuel cell temperature did not reach, but came close to, its design value of $353 \mathrm{~K}\left(80^{\circ} \mathrm{C}\right)$. During this time, the coolant was allowed to bypass the radiator, so that its temperature could increase as a result of the heat generated in the fuel cell. This is beneficial for the performance of the fuel cell. As the fuel cell temperature increased, the cell voltage increased, hence so did the system efficiency.

Figure 13 shows the time variation of the fuel cell system efficiency and its average value. The calculated fuel-cell system efficiency is between $56 \%$ and $65 \%$, with an average value approaching $60 \%$ near the end of the FUDS cycle. The efficiency dropped below $50 \%$ in a very few instances during the cycle, where the power demand was high, while the fuel cell temperature was still below its design value (see Fig. 12). Figure 14 presents the time variation of the overall vehicle efficiency and its average value over the cycle. The overall vehicle efficiency is lower than the fuel-cell system efficiency, as the auxiliary load $(2.3 \mathrm{~kW})$ is subtracted from the 


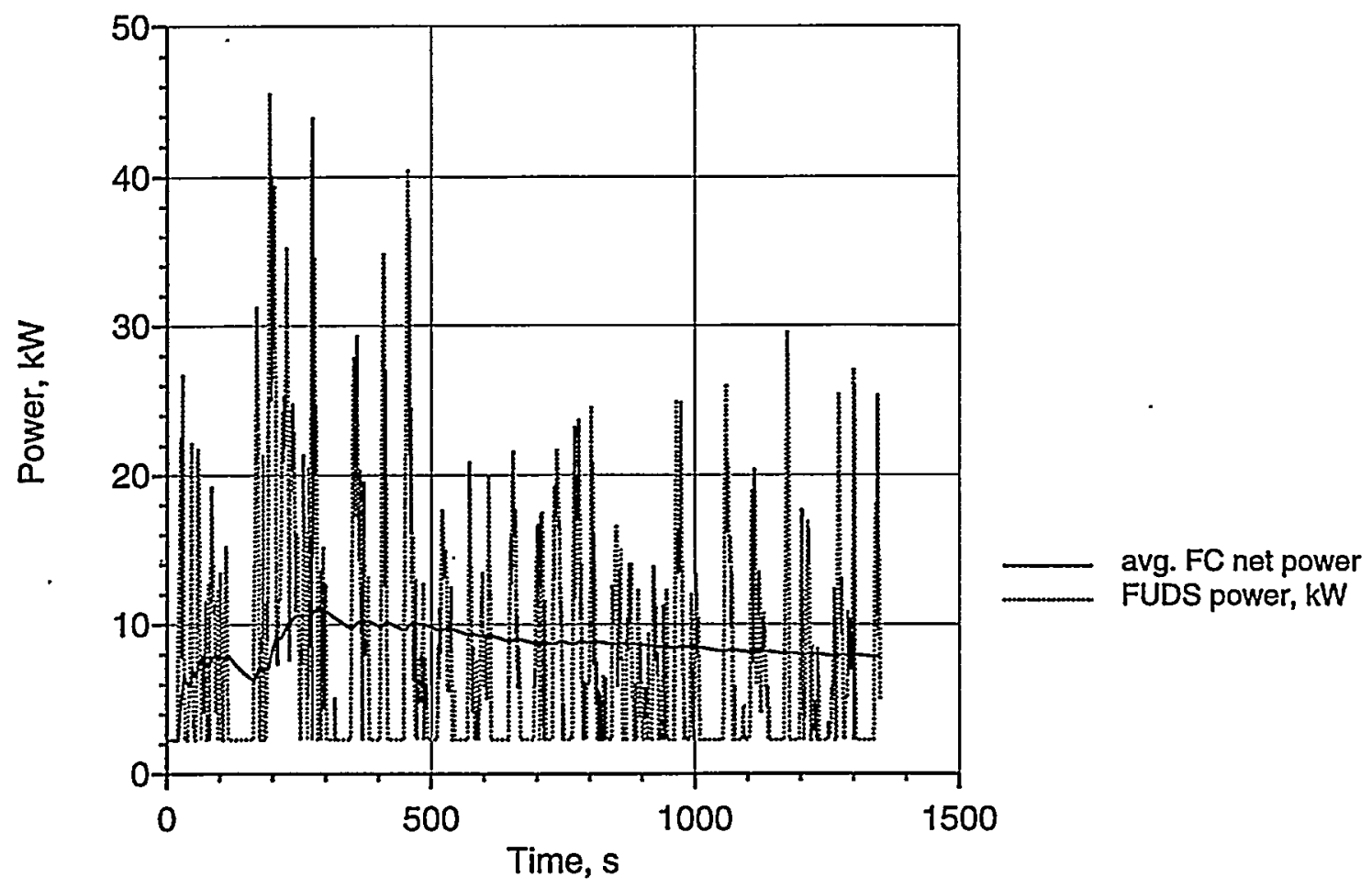

Fig. 11. Vehicle Power Requirements over the FUDS Cycle

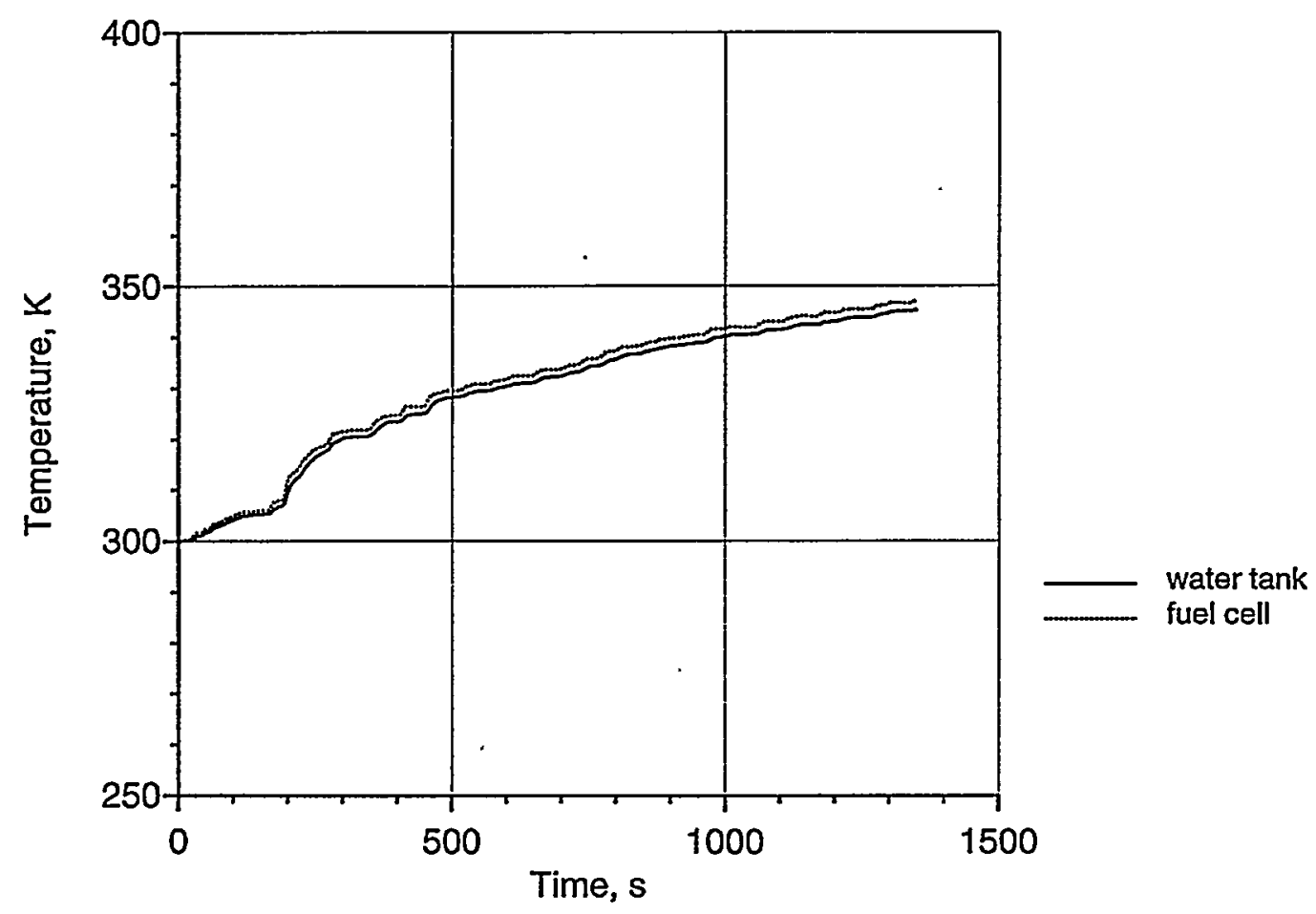

Fig. 12. Fuel Cell and Water-Tank Temperatures over the FUDS Cycle with the 50-kW Hydrogen-Fueled PEFC System - Starting Cold 


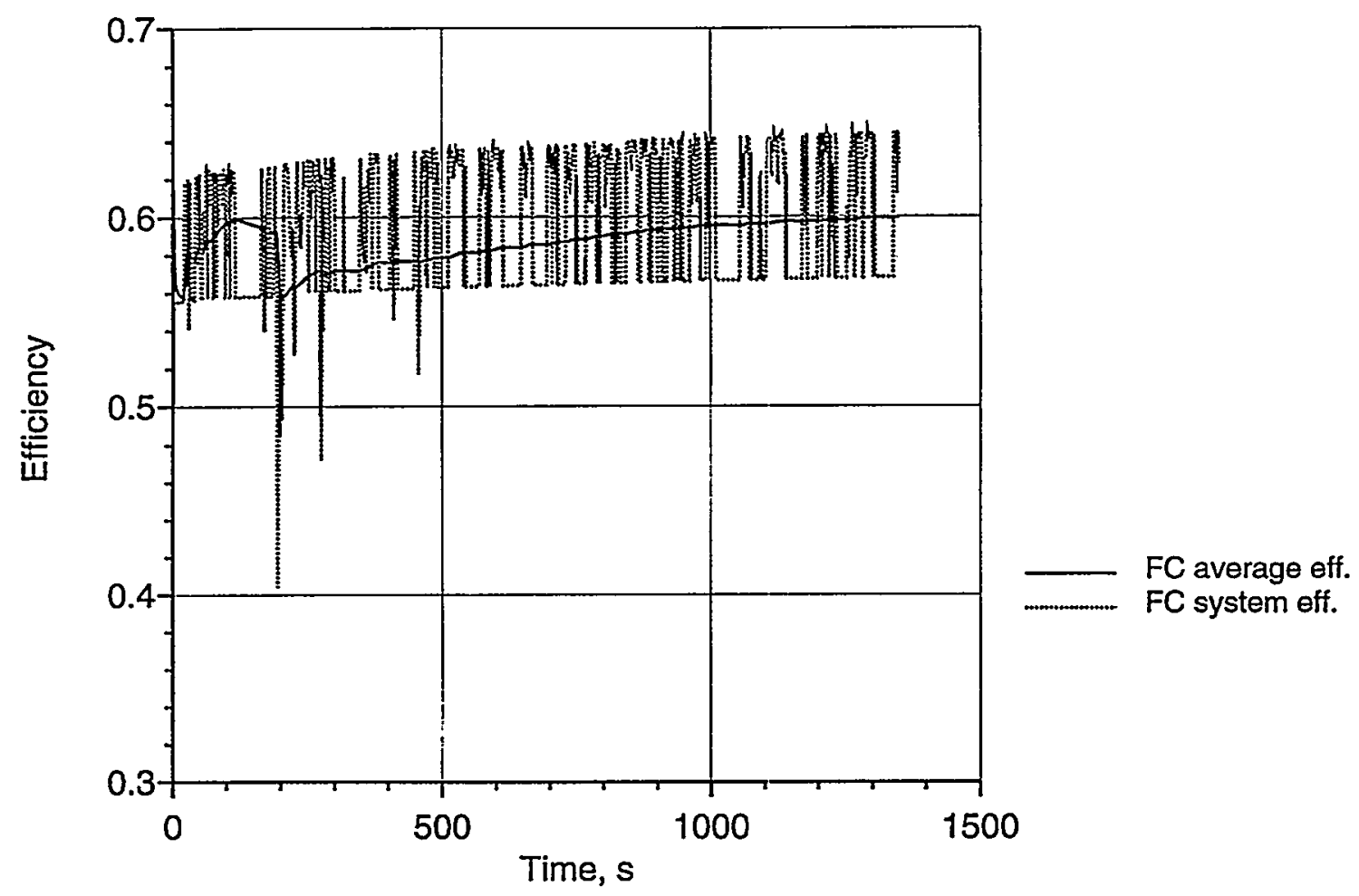

Fig. 13. Fuel Cell System Efficiency over the FUDS Cycle with the 50-kW Hydrogen-Fueled PEFC System - Starting Cold

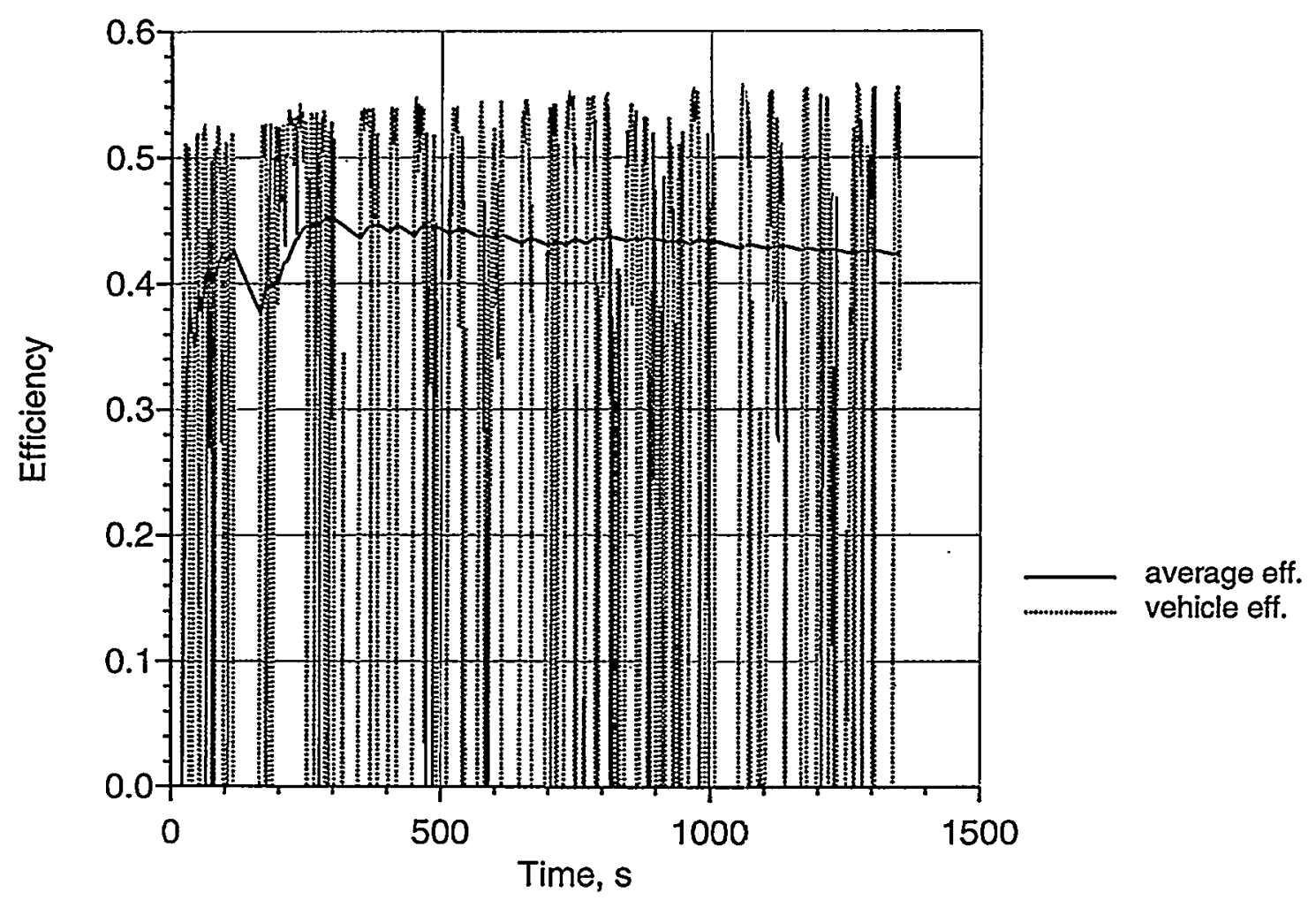

Fig. 14. Vehicle-Based Efficiency over the FUDS Cycle with the 50-kW Hydrogen-Fueled PEFC System - Starting Cold 


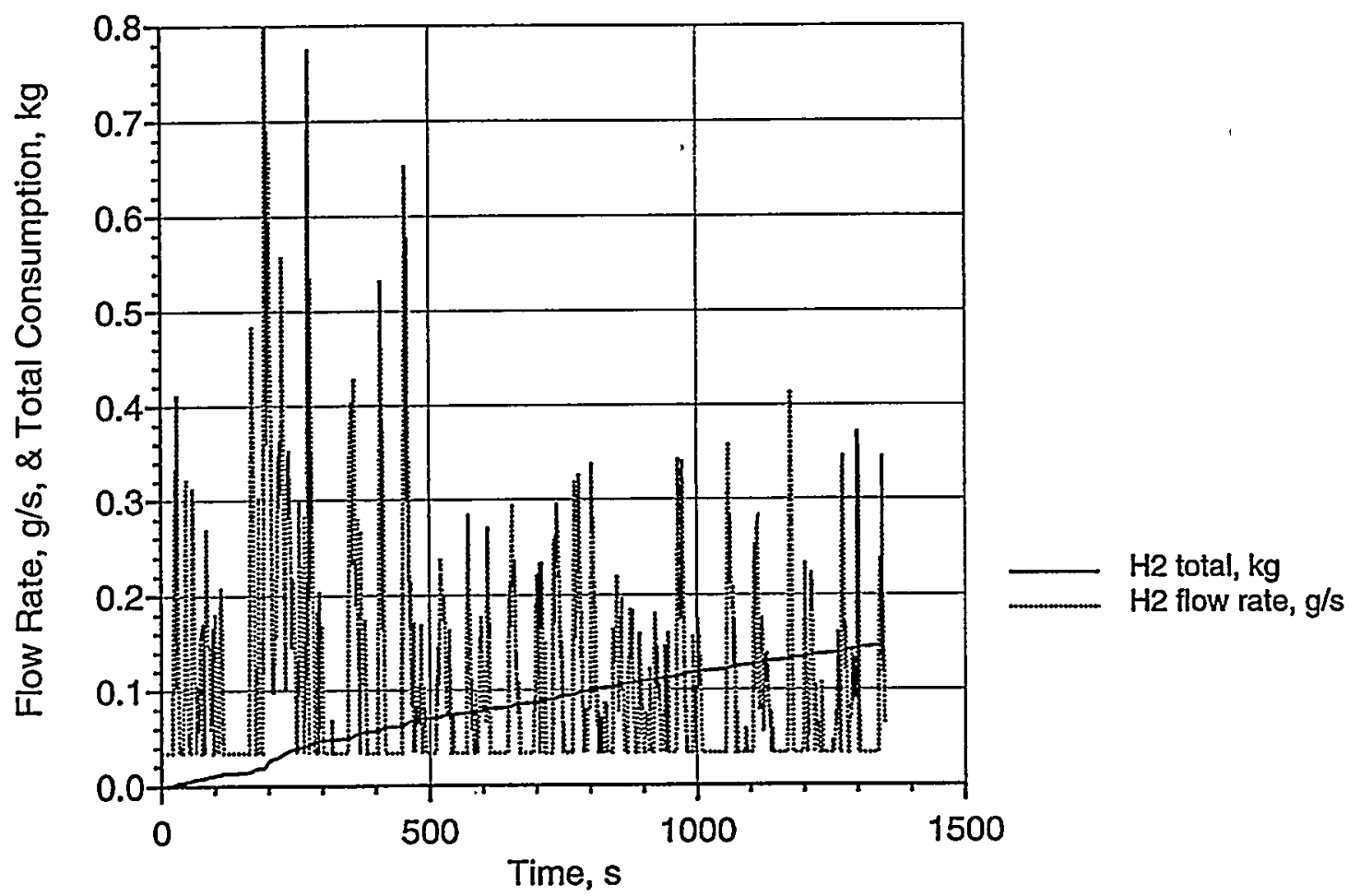

Fig. 15. Hydrogen Consumption over the FUDS Cycle with the 50-kW HydrogenFueled PEFC System - Starting Cold

fuel-cell system power. Whenever the FUDS cycle power requirement is equal to the auxiliary (parasitic) power, the vehicle drive power and overall efficiency become zero. The average vehicle-based efficiency was about $42.5 \%$ over the entire cycle.

Figure 15 presents the time variation of the hydrogen fuel mass flow rate and the cumulative fuel consumption over the cycle. The maximum hydrogen consumption rate is $0.8 \mathrm{~g} / \mathrm{s}$, while the cumulative fuel consumption over the cycle is approximately $0.15 \mathrm{~kg}$. The fuel demand curve, shown in Fig. 15, follows exactly the FUDS cycle power requirements shown in Fig. 11.

Similar results were obtained for the other three cases. Table 4 summarizes the results for the simulation study for the four cases. The bottom row represents the fuel consumption in terms of the equivalent miles per gallon of gasoline. For Case 2, the start-up fuel cell temperature was higher than in Case 1 , and only $6 \mathrm{~K}$ below its nominal design temperature $353 \mathrm{~K}\left(80^{\circ} \mathrm{C}\right)$. Therefore, the results of the simulation for Cases 2 and 3 are very close. For these two cases, the fuel cell and vehicle efficiency values are higher than the corresponding values shown for Case 1. The results for Case 4 (the 100-kW fuel-cell system, starting cold) show slightly higher efficiencies than the other cases. The reason is the following: while the power demand was the same, the power requirement over the FUDS cycle was smaller relative to the design power. The fuel cell in this case operated at much lower current densities, where the fuel cell voltage and efficiency were higher. 
Table 4. Summary of Results for Four FUDS Cases

\begin{tabular}{|c|c|c|c|c|}
\hline & Case 1 & Case 2 & Case 3 & Case 4 \\
\hline Startup Temp., ${ }^{\circ} \mathrm{C}$ & 27 & 74 & 80 & 27 \\
\hline Fuel Cell Efficiency, \% & 60.0 & 61.8 & 61.8 & 62.8 \\
\hline Vehicle Efficiency, \% & 42.5 & 43.8 & 43.8 & 44.5 \\
\hline Fuel Consumption, g & 148 & 144 & 144 & 141 \\
\hline Equivalent, mpg & 40.9 & 42.0 & 42.0 & 42.9 \\
\hline
\end{tabular}

In conclusion, the results of the analysis performed for the 50- and 100-kW hydrogenfueled PEFC systems indicate the following:

- The fuel cell system responds favorably to the demands of the FUDS cycle for the midsize vehicle considered, whether the vehicle starts cold or warm.

- A stand-alone 50-kW fuel cell system cannot meet the acceleration demand of 0 to $60 \mathrm{mph}$ in $12 \mathrm{~s}$. The maximum power required for this case is $97.7 \mathrm{~kW}$. Therefore, either a hybrid fuel cell-battery system must be used with a $50-\mathrm{kW}$ fuel cell system, or a standalone $100-\mathrm{kW}$ fuel cell system must be used.

\section{B. Analysis for Near-Term and Future Vehicles}

Two additional mid-size vehicles powered by fuel cells were simulated over the FUDS cycle and the Highway cycle. The data used in the analysis for these two vehicles are for the near-term Ford AIV (Aluminum Intensive Vehicle) Sable and the P2000 future vehicle. The simulation parameters for the two vehicles are given in Refs. 5 and 6 and are shown in Table 5.

Table 5. Simulation Parameters for the AIV Sable and P2000 Vehicles

\begin{tabular}{|l|c|c|}
\hline \multicolumn{1}{|c|}{ Parameter } & AIV Sable & P2000 \\
\hline Test Weight, kg & 1490 & 1043 \\
\hline Frontal Area, ${ }^{2}$ & 1.98 & 2.18 \\
\hline Drag Coefficient & 0.33 & 0.25 \\
\hline Rolling Resistance & 0.00776 & 0.0064 \\
\hline Wheel Radius, mm & 326 & 326 \\
\hline Auxiliary Load, kW & 1.0 & 0.5 \\
\hline
\end{tabular}


The variations of the vehicle speed over the FUDS and Highway driving cycles are presented in Figs. 10 and 16, respectively. The total distance covered in the course of the FUDS cycle is 7.45 miles over $1371 \mathrm{~s}$, and the corresponding values for the Highway driving cycle are 16.51 miles over $765 \mathrm{~s}$. Figures 17 through 20 show the computed instantaneous and the average (from the beginning of the cycle) power requirements for both the AIV Sable and the P2000 vehicles as driven on the FUDS and Highway cycles. The power requirements are lower for the P2000 vehicle, as this vehicle has less weight, lower drag resistance, and lower auxiliary load. The maximum power requirement for all cases is less than $40 \mathrm{~kW}$, while the maximum average power over the entire cycles is only about $6 \mathrm{~kW}$ for the FUDS cycle and about $12 \mathrm{~kW}$ for the Highway cycle.

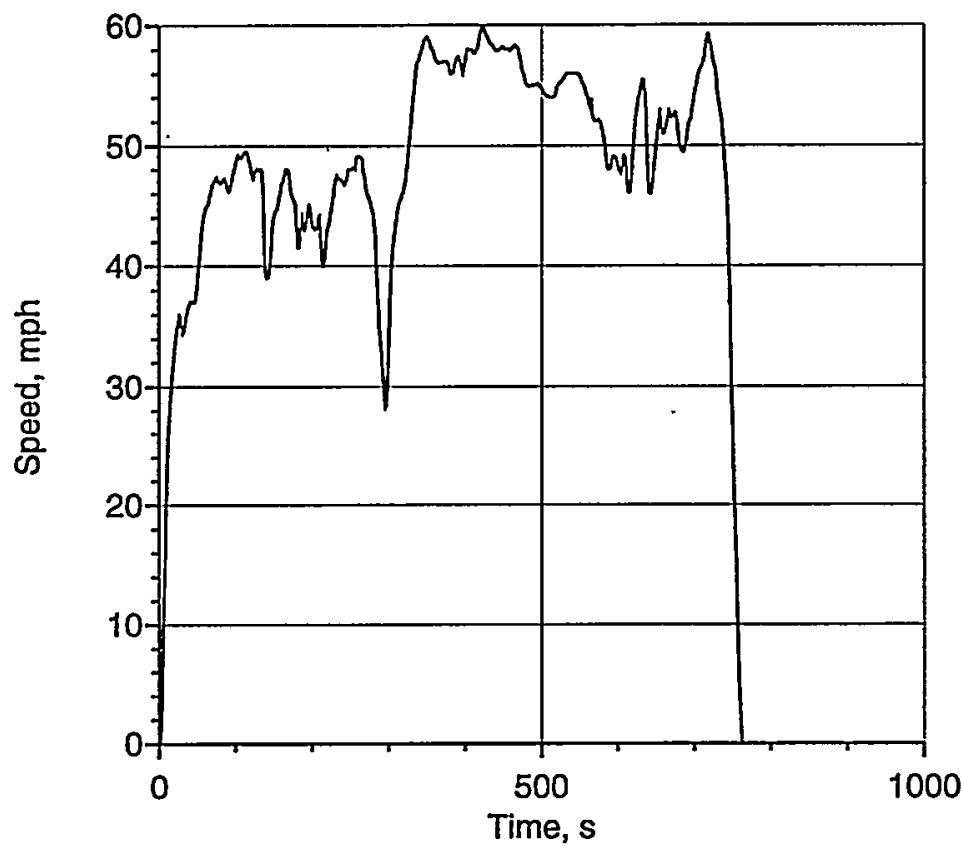

Fig. 16. Vehicle Speed vs. Time for the Highway Cycle

Another computation was performed to determine the power required for accelerating the vehicle from 0 to $60 \mathrm{mph}$ in $12 \mathrm{~s}$. The results indicate that for a stand-alone PEFC system, an $80-\mathrm{kW}$ (net) system is required to meet the acceleration demand. Therefore, another simulation was performed with an $80-\mathrm{kW}$ system. This system was used to study the performance of the two vehicles over the two driving cycles.

The following cases were investigated for the two vehicles:

Case 1: Starting the FUDS cycle from the system's design point, where the cell temperature is $353 \mathrm{~K}\left(80^{\circ} \mathrm{C}\right)$ and the ambient temperature is $300 \mathrm{~K}\left(27^{\circ} \mathrm{C}\right)$.

Case 2: Starting the FUDS cycle cold, where all system components are at the ambient temperature of $300 \mathrm{~K}$. 
Case 3: Starting the Highway cycle from the system's design point, where the cell temperature is $353 \mathrm{~K}\left(80^{\circ} \mathrm{C}\right)$ and the ambient temperature is $300 \mathrm{~K}$.

Case 4: Starting the Highway cycle cold, where all system components are at the ambient temperature of $300 \mathrm{~K}$.

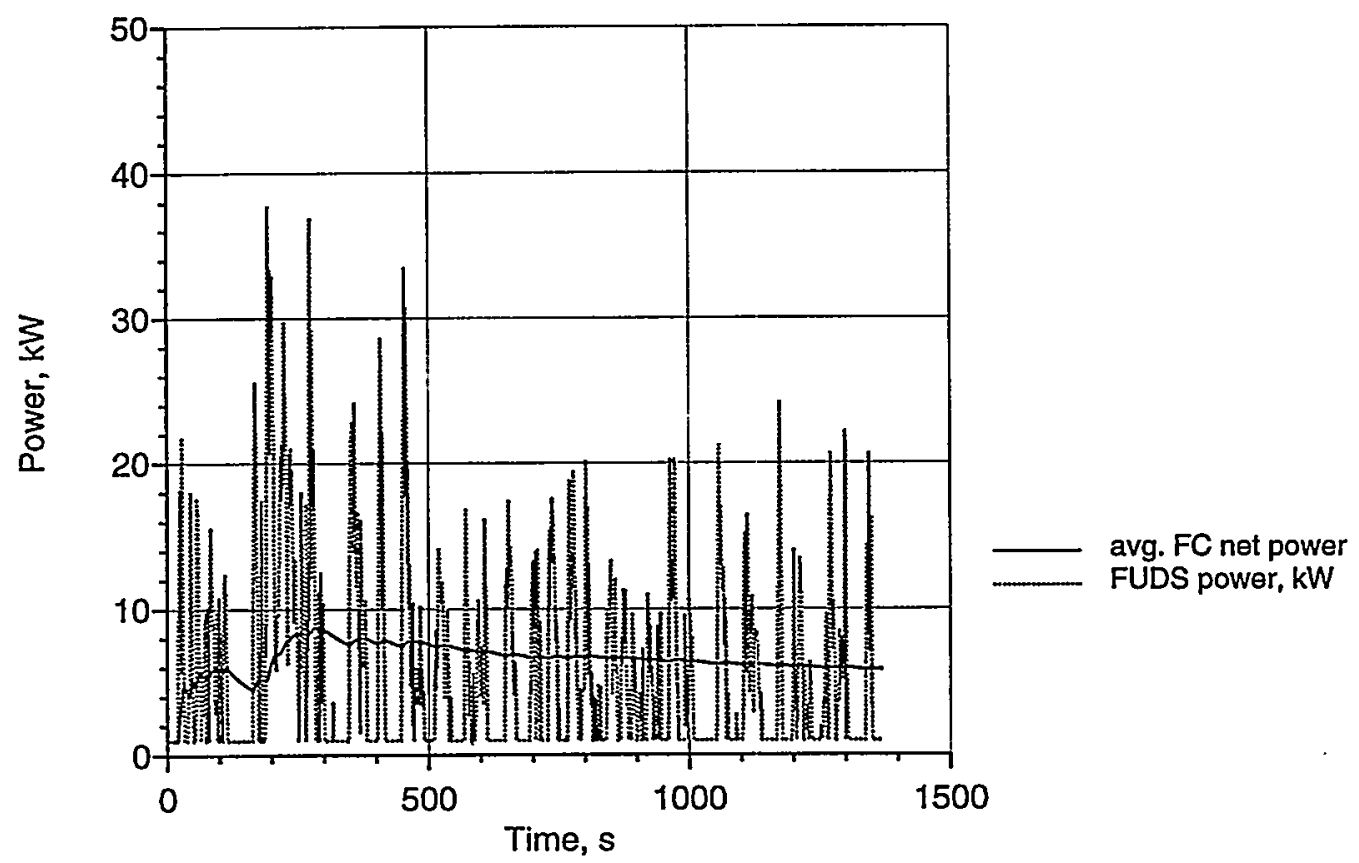

Fig. 17. FUDS Cycle Power Requirement for the AIV Sable

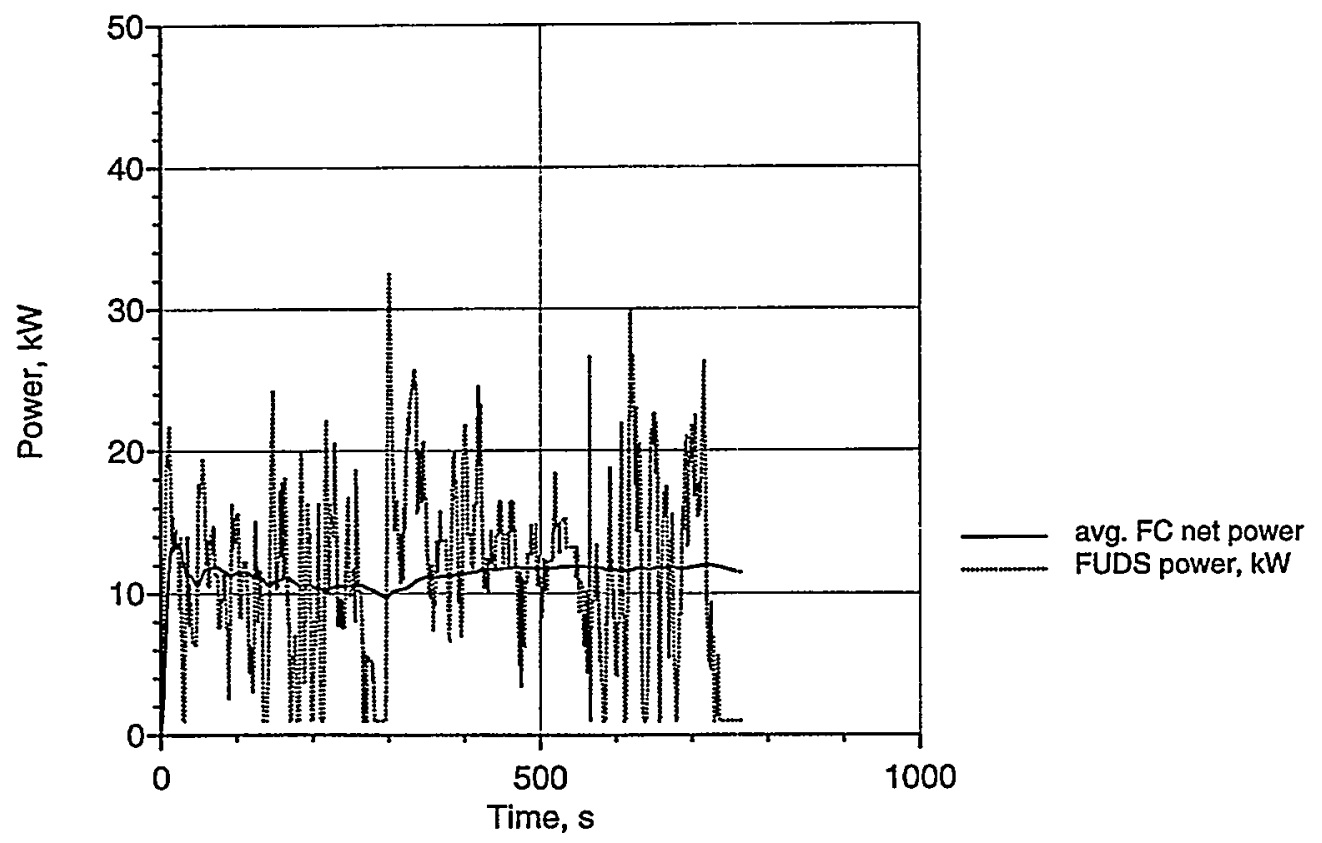

Fig. 18. Highway Cycle Power Requirement for the AIV Sable 


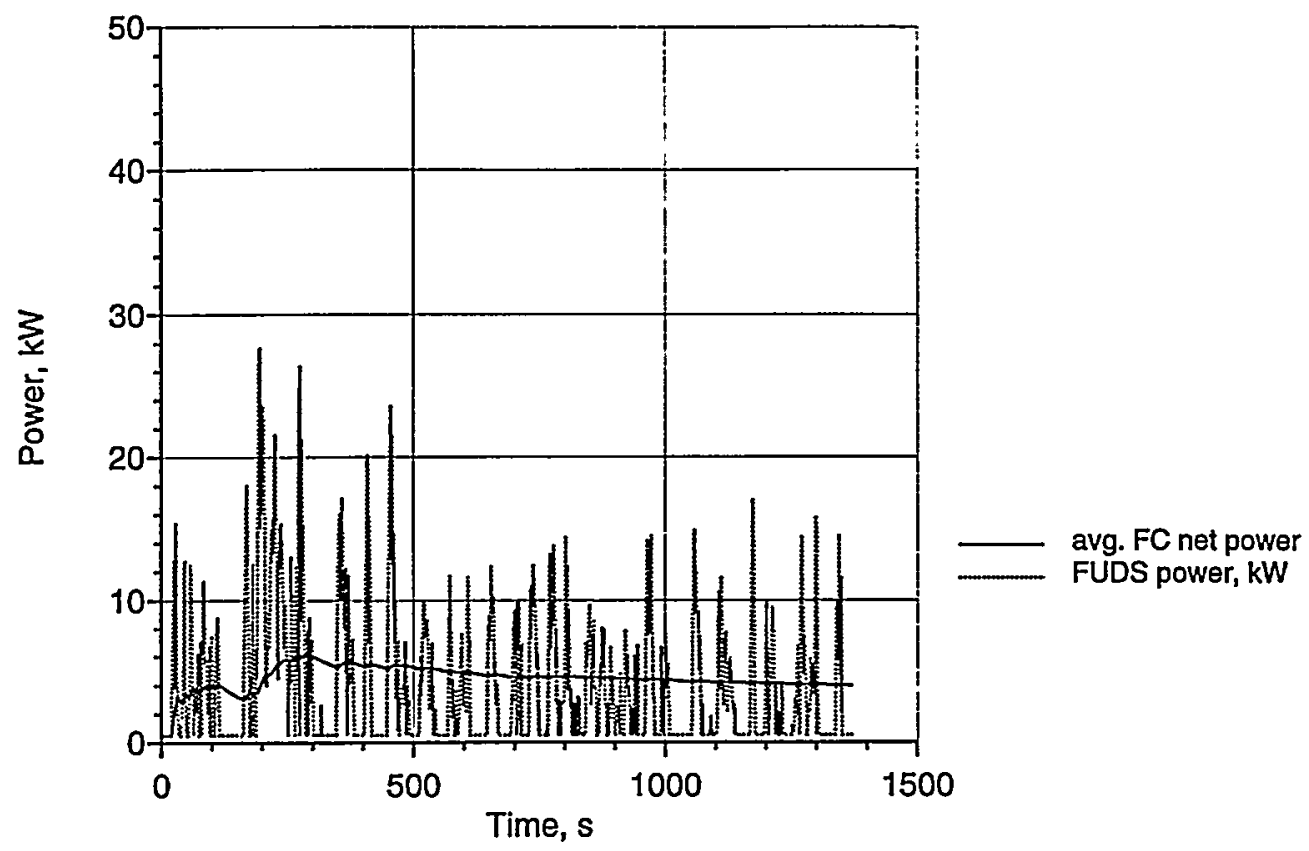

Fig. 19. FUDS Cycle Power Requirement for the P2000 Vehicle

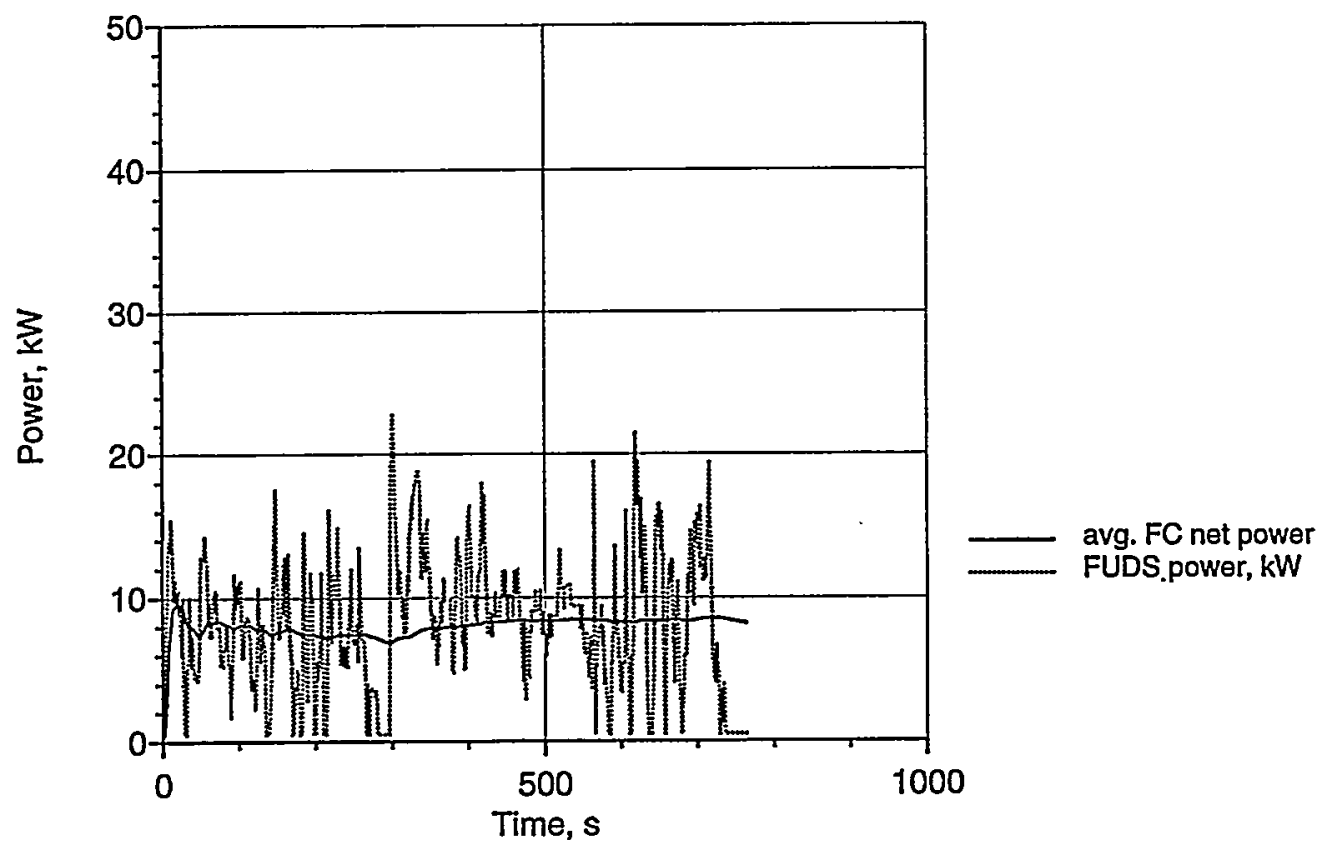

Fig. 20. Highway Cycle Power Requirement for the P2000 Vehicle

For the analyses of these eight cases, the efficiencies of the fans, expander, and compressor were kept constant at 0.8 . The results obtained can be viewed as showing the upper limit for the performance of the vehicles. The analyses were repeated (eight more cases), except that the efficiencies were assumed to vary with the flow rate ratio relative to the design value by a factor of 1.0 at the 0.6 ratio and above, 0.9 at the 0.4 ratio, 0.6 at the 0.2 ratio, and 0.3 at the 0.1 ratio. 
Figures 21 through 24 show the results for one of the 16 cases considered: the Ford AIV Sable over the Highway cycle, starting from the design-point $353 \mathrm{~K}\left(80^{\circ} \mathrm{C}\right)$ cell temperature. Figure 21 presents the time variation of the temperatures of the fuel cell and coolant inside the tank. The coolant temperature in the tank started at $323 \mathrm{~K}\left(50^{\circ} \mathrm{C}\right)$ and then increased with time by the heat generated inside the fuel cell. On the other hand, because the fuel cell was operating at partial load during the entire cycle, its temperature dropped slightly from its design value. As the coolant temperature approached the fuel-cell temperature, a controlling mechanism similar to a vehicle's radiator thermostat was activated. The coolant was allowed to flow through the radiator to be cooled down. As this occurred, the coolant temperature dropped, the flow of coolant bypassed the radiator, and its water temperature once again started to increase. This process was repeated, leading to the seesaw variation in the coolant temperature shown in Fig. 21.

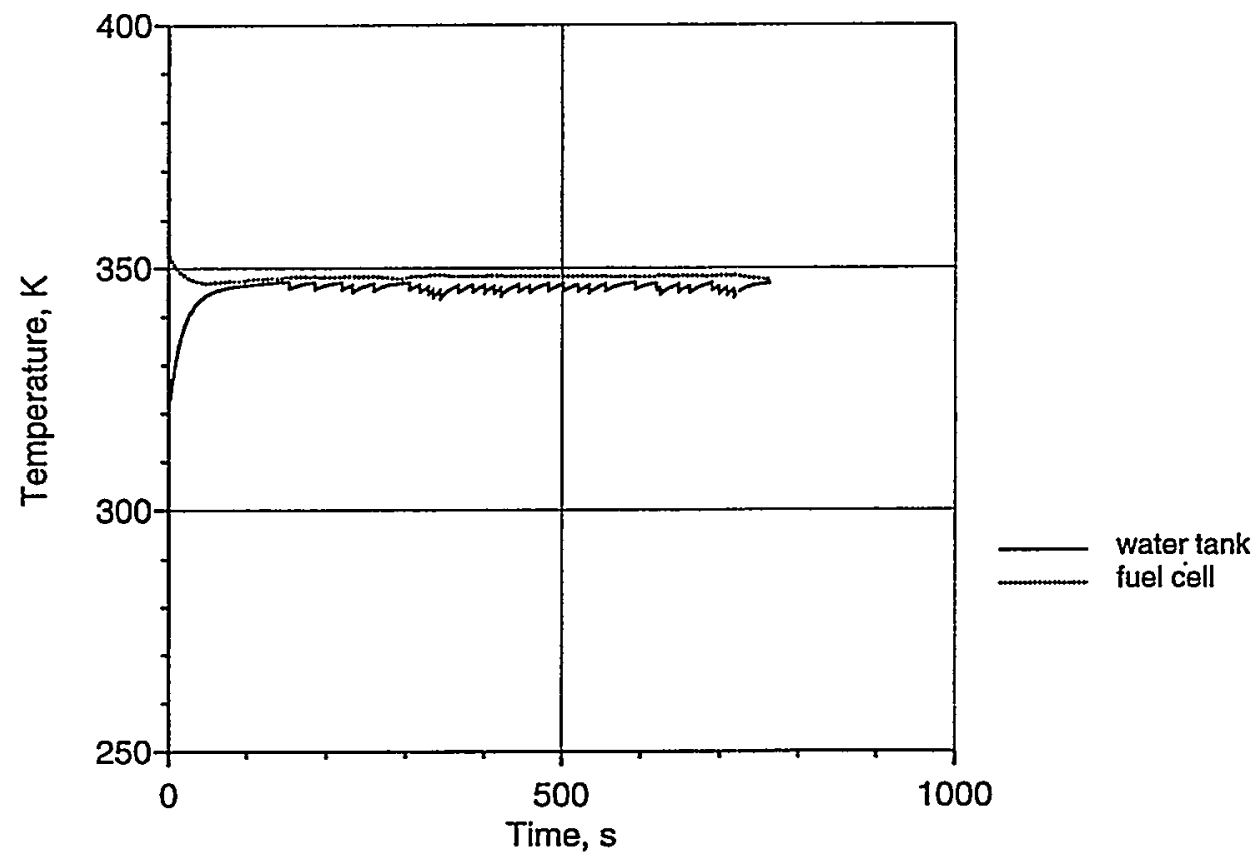

Fig. 21. Fuel-Cell and Water-Tank Temperatures for 80-kW PEFC System in the AIV Sable Operated on the Highway Cycle

Figure 22 shows the time variation of the fuel-cell system efficiency and its average value. The calculated fuel-cell system efficiency is between $66 \%$ and $70 \%$ most of the time, with an average value approaching $68 \%$ near the end of the Highway cycle. Figure 23 presents the corresponding variation of the overall vehicle efficiency and its average value over time. The overall vehicle efficiency is lower than the fuel-cell system efficiency, as the auxiliary power $(1.0 \mathrm{~kW})$ is subtracted from the highway power requirement for the fuel-cell system. Wherever the cycle power requirement is equal to the auxiliary power, the vehicle drive power and overall efficiency become zero. Figure 24 shows the time variation of the fuel (hydrogen) mass flow rate and the cumulative fuel consumption over the cycle. The fuel demand curve follows exactly the highway power requirement presented in Fig. 18. 


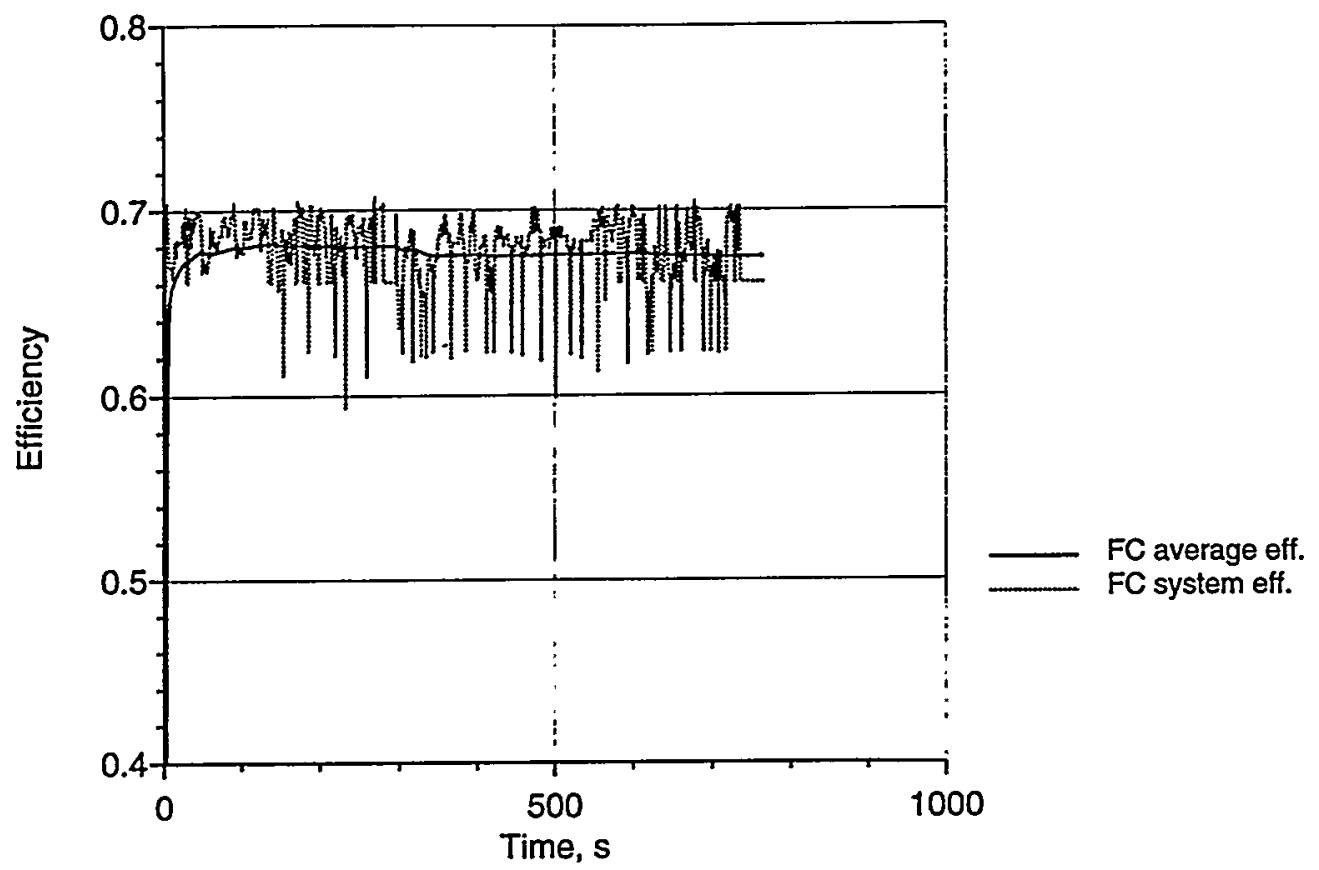

Fig. 22. Fuel-Cell System Efficiency for 80-kW PEFC System in the AIV Sable Operated on the Highway Cycle

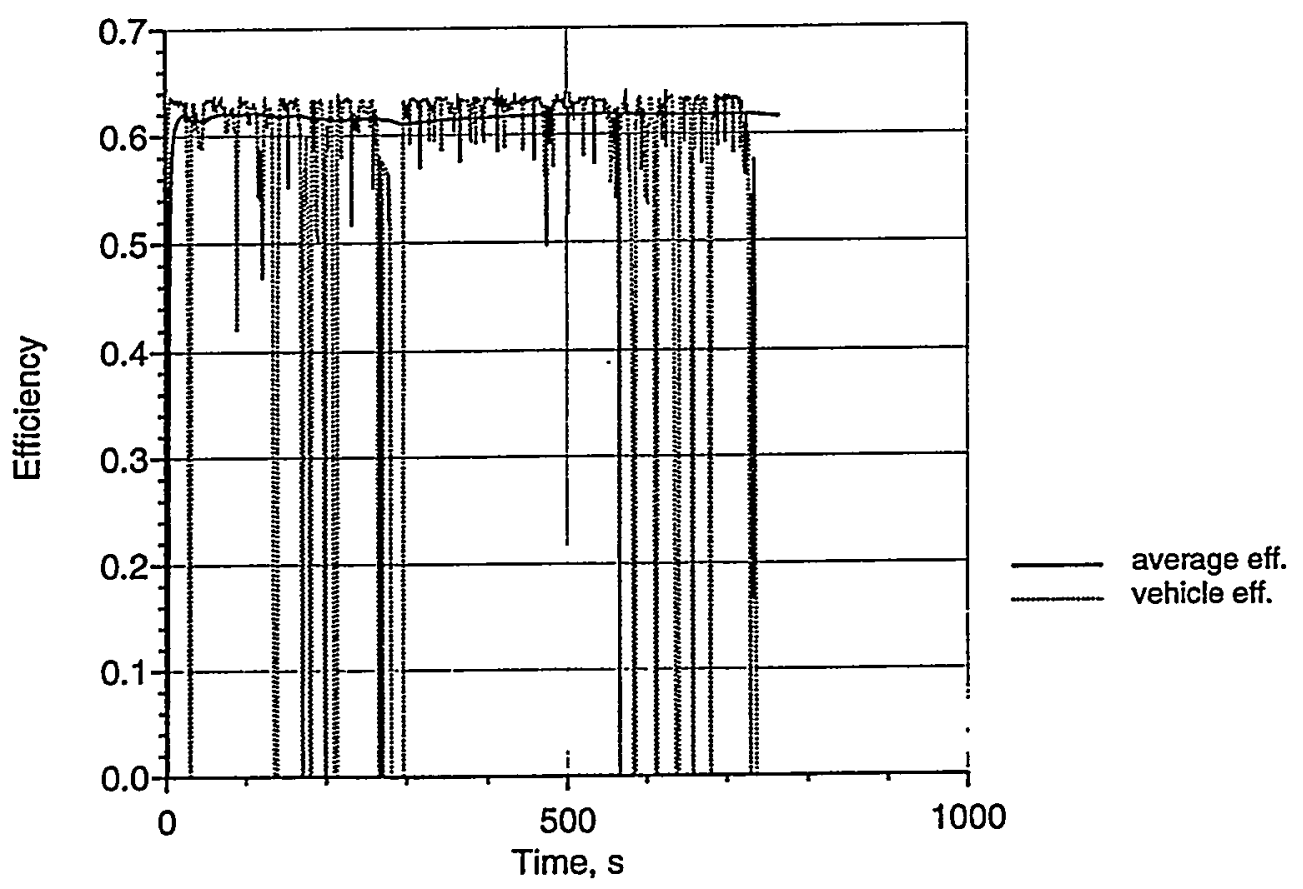

Fig. 23. Vehicle-Based Efficiency for 80-kW PEFC System in the ATV Sable Operated on the Highway Cycle 


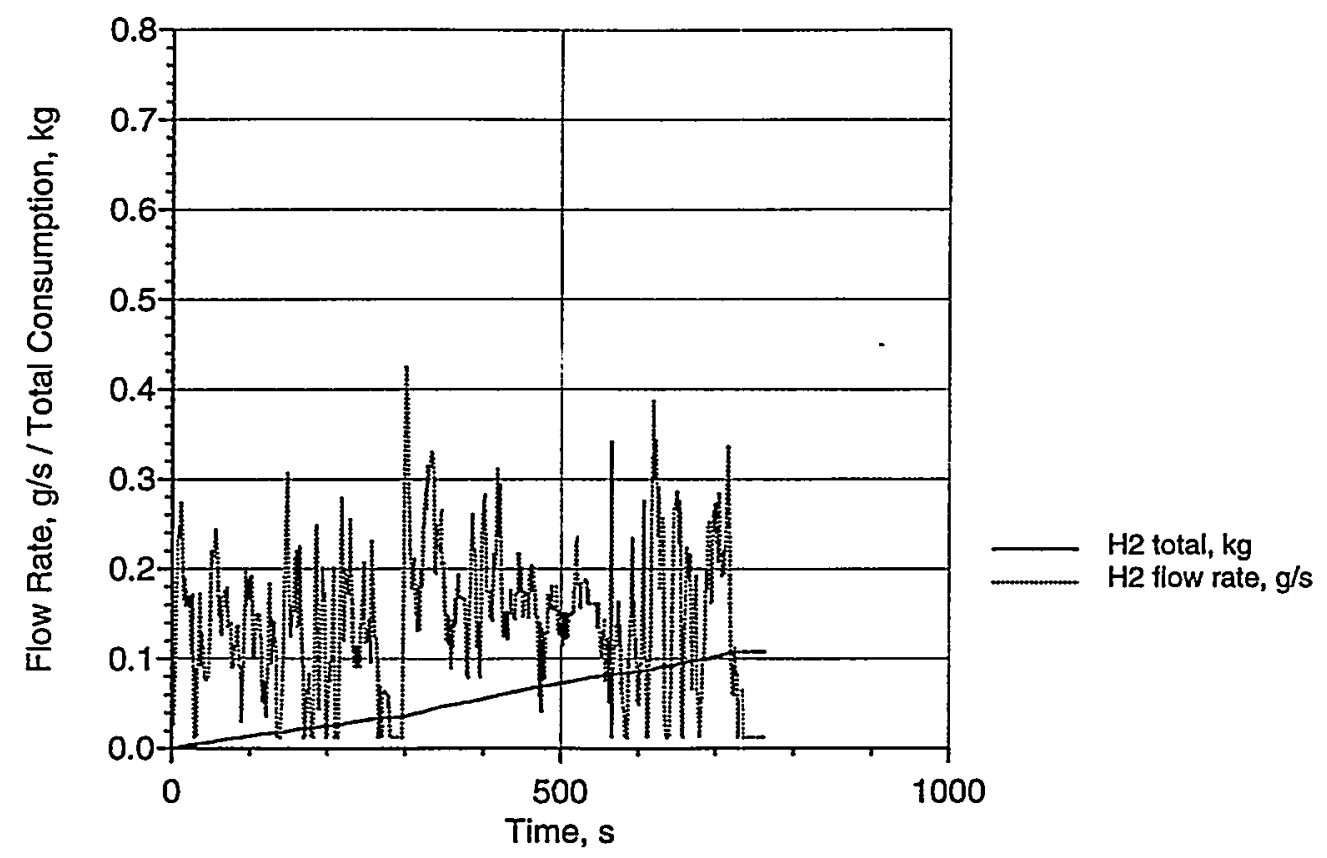

Fig. 24. Hydrogen Consumption for $80-\mathrm{kW}$ PEFC System in the AIV Sable Operated on the Highway Cycle

Similar results were obtained for the other 15 cases. The results for the calculated cell efficiency, vehicle efficiency, and fuel economy in equivalent miles per gallon of gasoline are shown in Table 6 and Fig. 25. The fuel economy on the FUDS, the Highway, and the combined driving cycles is shown. The combined fuel economy of the two driving cycles is calculated as the harmonic average of the two cycles:

$$
(1 / \text { combined })=0.5(1 / \text { FUDS }+1 / \text { Highway })
$$

The results given in Table 6 and Fig. 25 illustrate the effect of the compressor and expander efficiencies on the vehicle performance. With variable compressor and expander efficiencies (which drop with decreasing flow rates), the vehicle's system efficiencies drop significantly, and so does the fuel economy. 
Table 6. Performance Summary of the 80-kW AIV Sable and P2000 Vehicles with Constant and Variable Compressor and Expander Efficiencies

\begin{tabular}{|c|c|c|c|c|c|c|c|c|c|}
\hline \multicolumn{3}{|c}{ Parameter } & \multicolumn{3}{c|}{ FUDS Cycle } & \multicolumn{3}{c|}{ Highway Cycle } & Combined \\
\hline Case & Startup & $\begin{array}{c}\text { Efficiency, } \\
\text { Compressor/ } \\
\text { Expander }\end{array}$ & $\begin{array}{c}\text { FC } \\
\text { Eff. }\end{array}$ & $\begin{array}{c}\text { Veh. } \\
\text { Eff. }\end{array}$ & mpg & $\begin{array}{c}\text { FC } \\
\text { Eff. }\end{array}$ & $\begin{array}{c}\text { Veh. } \\
\text { Eff. }\end{array}$ & mpg & mpg \\
\hline AIV & warm & $\begin{array}{c}\text { Const. } \\
0.8\end{array}$ & 0.68 & 0.56 & 62.2 & 0.68 & 0.62 & 77.9 & 69.2 \\
\hline AIV & cold & $\begin{array}{c}\text { Const. } \\
0.8\end{array}$ & 0.66 & 0.55 & 60.5 & 0.66 & 0.60 & 75.8 & 67.3 \\
\hline P2000 & warm & $\begin{array}{c}\text { Const. } \\
0.8\end{array}$ & 0.68 & 0.60 & 91.6 & 0.69 & 0.64 & 110.7 & 100.3 \\
\hline P2000 & cold & $\begin{array}{c}\text { Const. } \\
0.8\end{array}$ & 0.67 & 0.58 & 89.9 & 0.67 & 0.63 & 108.2 & 97.5 \\
\hline AIV & warm & vary & 0.53 & 0.44 & 48.7 & 0.56 & 0.51 & 64.2 & 55.4 \\
\hline AIV & cold & vary & 0.52 & 0.43 & 48.1 & 0.55 & 0.50 & 63.3 & 54.7 \\
\hline P2000 & warm & vary & 0.51 & 0.44 & 68.5 & 0.54 & 0.50 & 86.8 & 76.5 \\
\hline P2000 & cold & vary & 0.50 & 0.44 & 67.5 & 0.53 & 0.50 & 85.7 & 75.5 \\
\hline
\end{tabular}

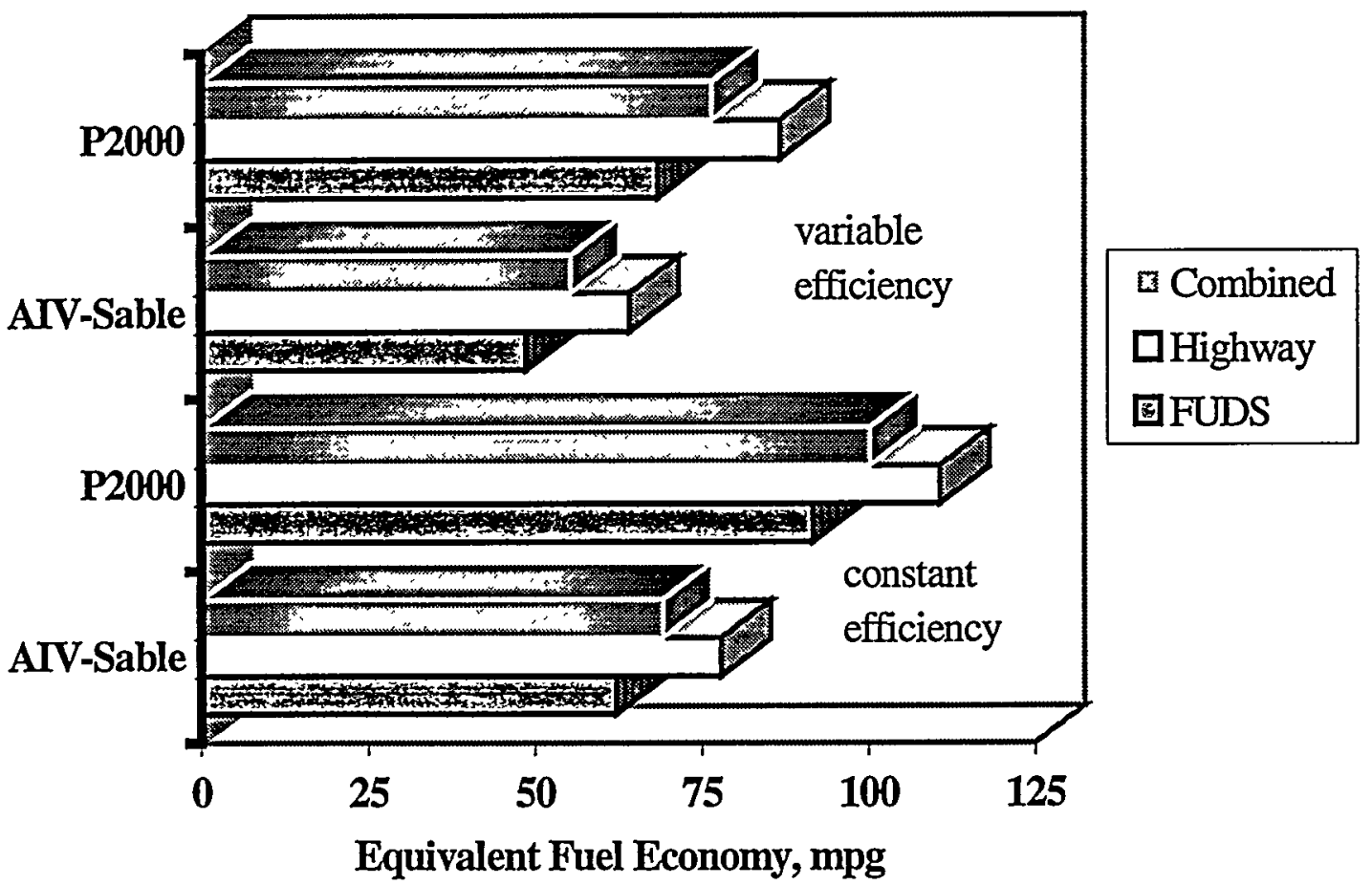

Fig. 25. Fuel Economy of the AIV Sable and the P2000 Vehicles with 80-kW PEFC System under the FUDS, Highway, and Combined Driving Cycles 
In general, the results indicate that the fuel-cell-powered AIV Sable would show impressive gains in fuel economy over that of the internal combustion engine vehicle. However, it is not able to meet the Partnership for a New Generation of Vehicles (PNGV) goal of $80 \mathrm{mpg}$. On the other hand, the P2000 vehicle approaches this goal with variable compressor and expander efficiencies. It is expected even to exceed that goal if the efficiency of the compressor and the expander can be maintained constant $(0.8)$ over the operating power range.

Another parametric simulation study was performed for the two mid-size vehicles using a 40-kW PEFC system tested over the two driving cycles. A schematic of this system and the state points for the steady-state conditions at the design point are shown in Fig. 26. Eight new cases were investigated for the 40-kW PEFC system. These cases are identical to the ones described for the $80-\mathrm{kW}$ system. However, these new cases are for constant compressor and expander efficiencies (0.8). Table 7 gives a summary of the performance of this system for the eight cases considered in terms of the fuel cell efficiency, vehicle efficiency, and the fuel economy expressed as the equivalent miles per gallon of gasoline.

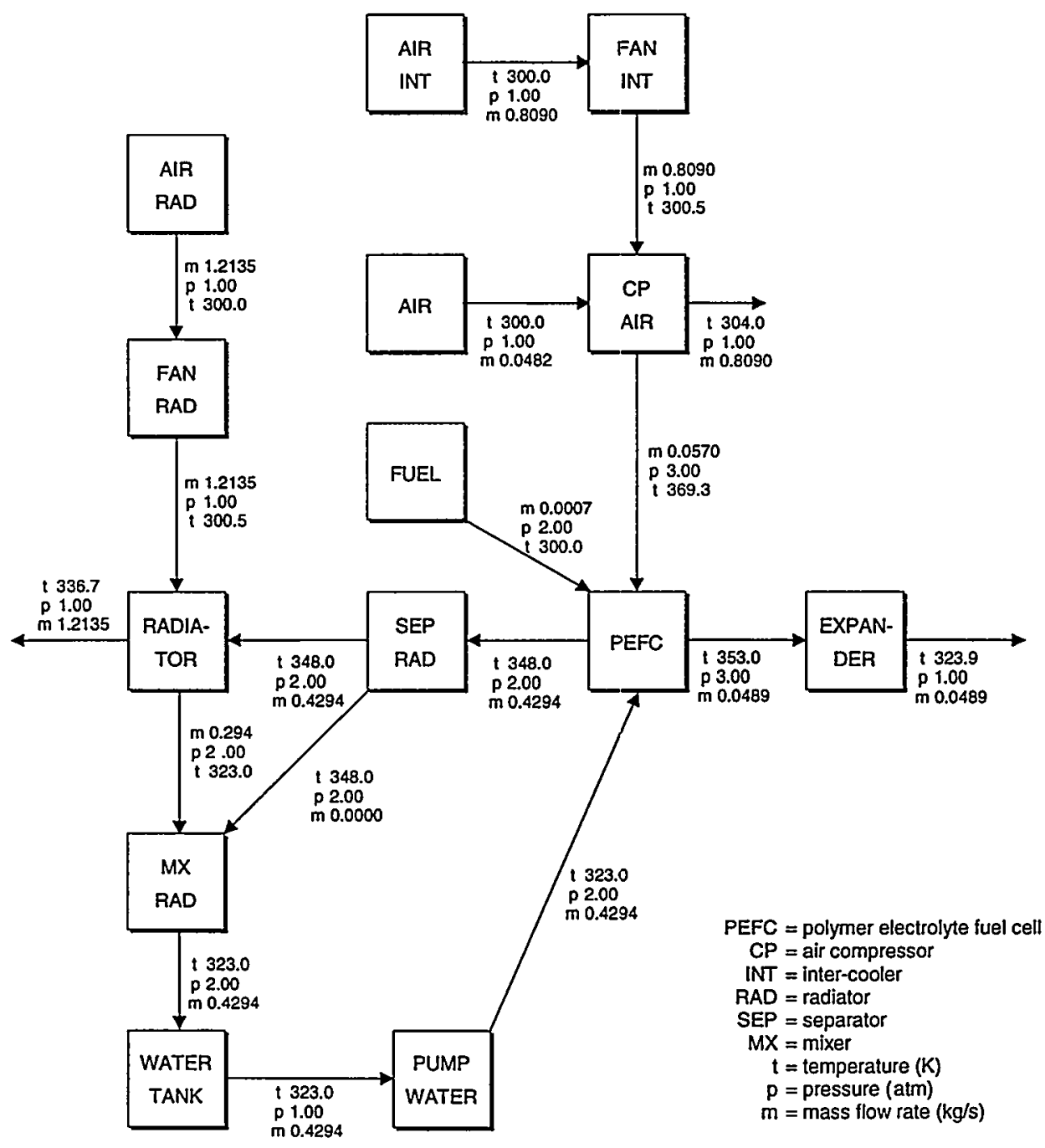

Fig. 26. Compressed Hydrogen-Fueled PEFC System (40 kW) 
Table 7. Performance Summary of AIV Sable and P2000 Vehicles with 40-kW PEFC System with Constant Compressor and Expander Efficiencies

\begin{tabular}{|c|c|c|c|c|c|c|c|c|c|}
\hline \multicolumn{4}{|c|}{ Parameter } & \multicolumn{3}{c|}{ FUDS Cycle } & \multicolumn{2}{c|}{ Highway Cycle } & Combined \\
\hline Case & Startup & $\begin{array}{c}\text { Efficiency, } \\
\text { Compressor } \\
\text { Expander }\end{array}$ & $\begin{array}{c}\text { FC } \\
\text { Eff. }\end{array}$ & $\begin{array}{c}\text { Veh. } \\
\text { Eff. }\end{array}$ & mpg & $\begin{array}{c}\text { FC } \\
\text { Eff. }\end{array}$ & $\begin{array}{c}\text { Veh. } \\
\text { Eff. }\end{array}$ & mpg & mpg \\
\hline AIV & warm & $\begin{array}{c}\text { Const. } \\
0.8\end{array}$ & 0.64 & 0.53 & 59.1 & 0.64 & 0.58 & 73.4 & 65.4 \\
\hline AIV & cold & $\begin{array}{c}\text { Const. } \\
0.8\end{array}$ & 0.62 & 0.52 & 57.0 & 0.62 & 0.56 & 71.3 & 63.3 \\
\hline P2000 & warm & $\begin{array}{c}\text { Const. } \\
0.8\end{array}$ & 0.66 & 0.58 & 89.0 & 0.64 & 0.62 & 106.2 & 96.8 \\
\hline P2000 & cold & $\begin{array}{c}\text { Const. } \\
0.8\end{array}$ & 0.64 & 0.56 & 86.1 & 0.64 & 0.60 & 103.3 & 93.9 \\
\hline
\end{tabular}

Figures 27 through 30 show the results for one of these cases for the AIV Sable vehicle operating over the Highway driving cycle and starting at the ambient temperature of $300 \mathrm{~K}$ $\left(27^{\circ} \mathrm{C}\right)$. The results for all cases show, in general, similar trends to the results presented before for the $80-\mathrm{kW}$ system. However, comparing the results given in Tables 6 and 7 for the two systems indicates that the fuel cell stack and overall vehicle efficiencies are slightly lower for the smaller system $(40 \mathrm{~kW})$. The fuel cell stack for the $40-\mathrm{kW}$ system operates at a relatively higher current density and a. lower cell voltage. This leads to the lower efficiencies and, correspondingly, to reduced fuel economy in terms of equivalent miles per gallon. Another

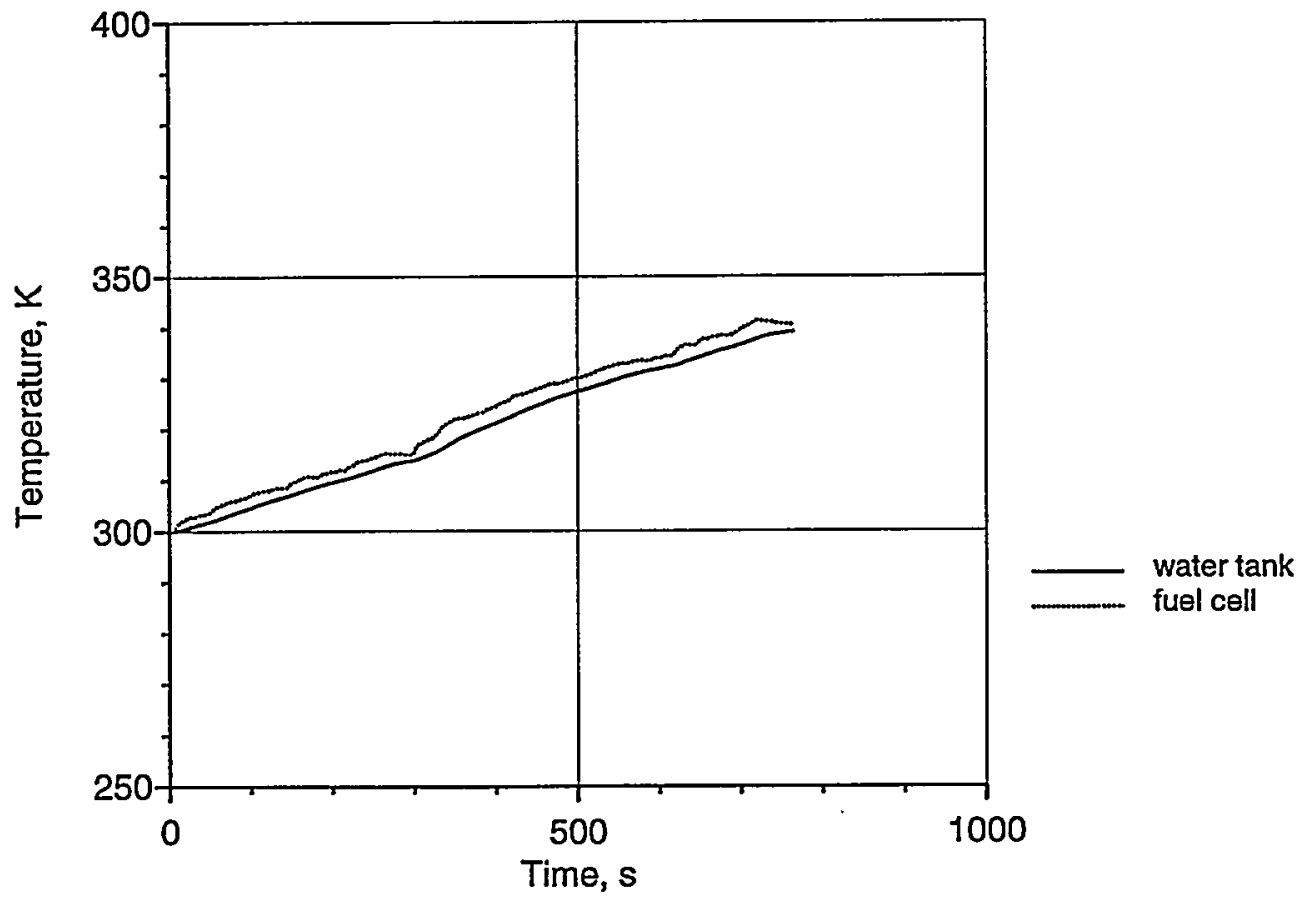

Fig. 27. Fuel-Cell and Water-Tank Temperatures for 40-kW PEFC System in the AIV Sable Operated on the Highway Cycle 
observation about the results for the cold start from $300 \mathrm{~K}$ is that the fuel cell and coolant temperatures increased with time at a much faster rate for the smaller system. For example, at the end of the Highway cycle, the fuel cell temperature reached $340 \mathrm{~K}$ for the $40-\mathrm{kW}$ system (as shown on Fig. 27) as compared to $322 \mathrm{~K}$ for the $80-\mathrm{kW}$ system.

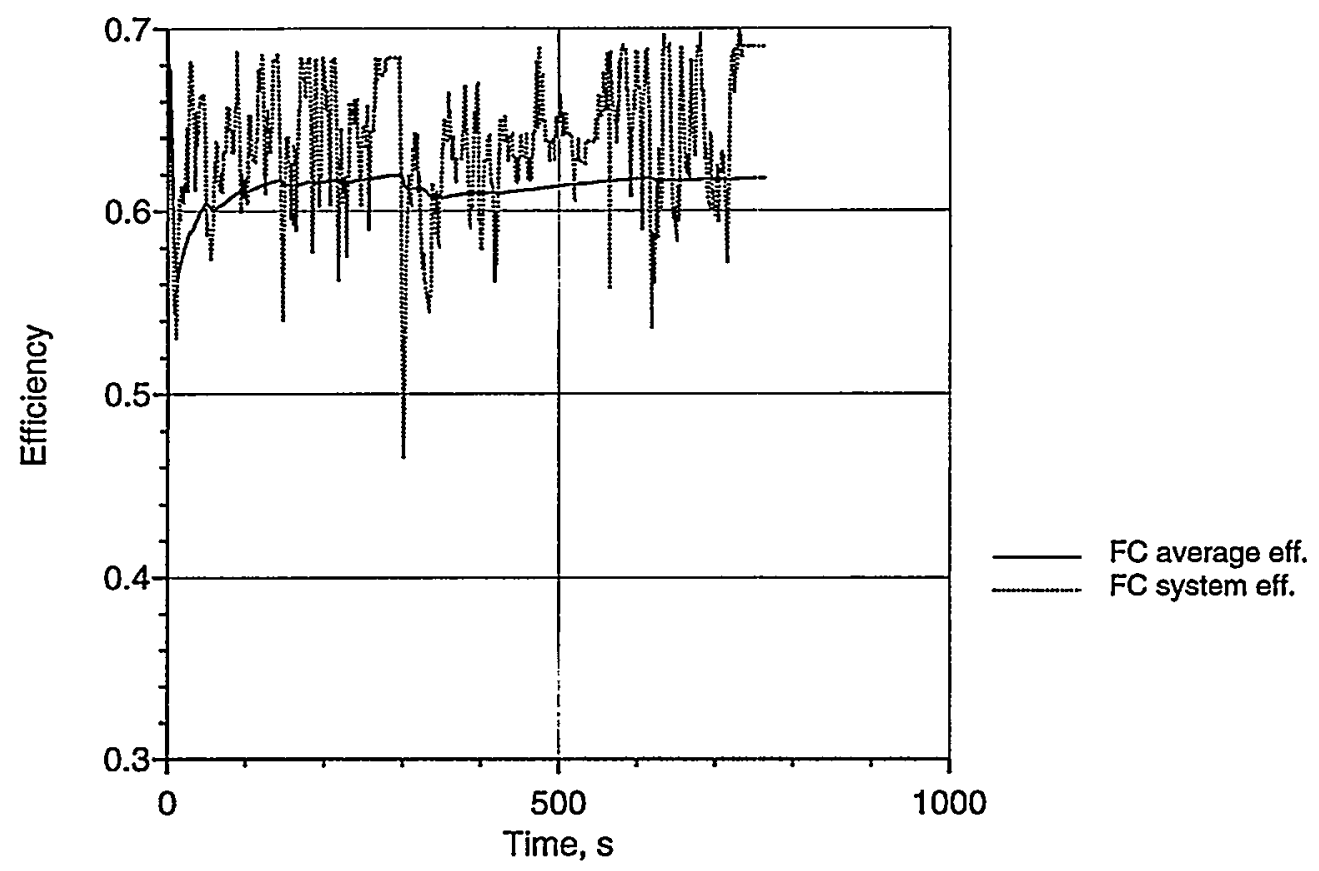

Fig. 28. Fuel Cell Efficiency for 40-kW PEFC System in the AIV Sable Operated on the Highway Cycle

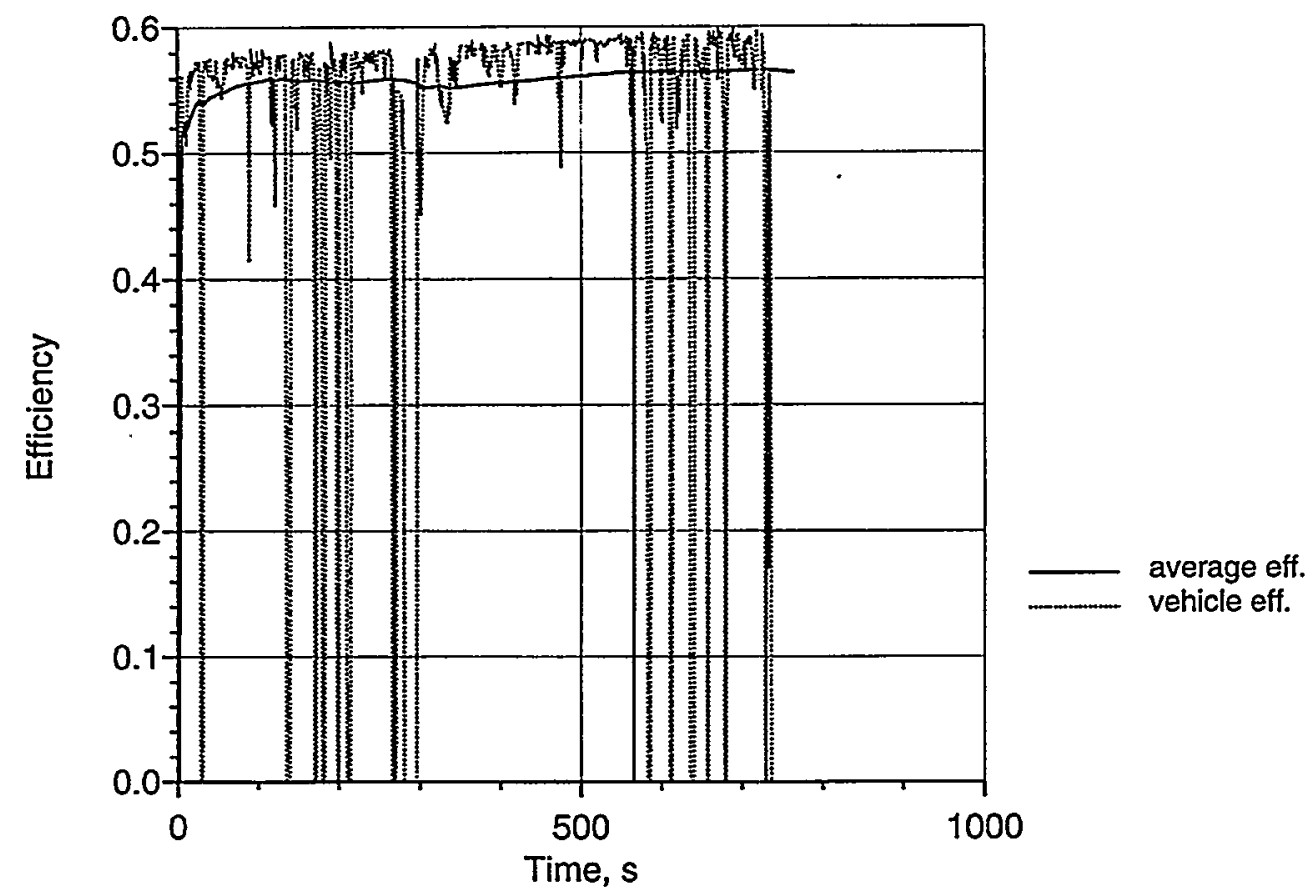

Fig. 29. Vehicle-Based Efficiency for 40-kW PEFC System in the AIV Sable Operated on the Highway Cycle 
As presented before, the $40-\mathrm{kW}$ PEFC system should be adequate to operate both vehicles over the two cycles. However, an extra source of power would be required to meet the performance criterion of accelerating the vehicles from 0 to $60 \mathrm{mph}$ in $12 \mathrm{~s}$. For that, the vehicles could be driven by a fuel cell-battery hybrid system.

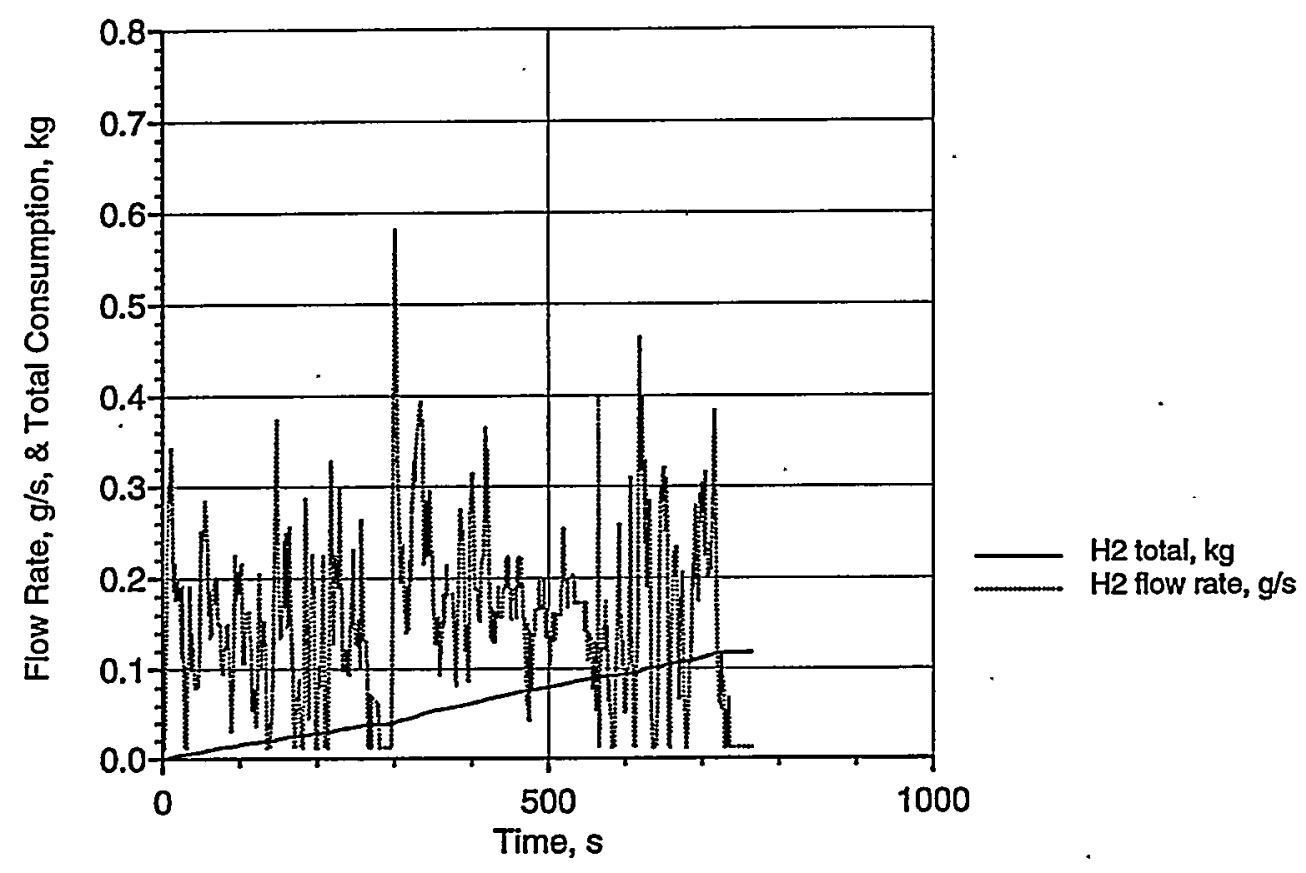

Fig. 30. Hydrogen Consumption for 40-kW PEFC System in the AIV Sable Operated on the Highway Cycle 


\section{SUMMARY AND CONCLUSIONS}

(1) The performance of the stand-alone direct-hydrogen-fueled PEFC system has been studied for transportation vehicles. The study was carried out using the systems analysis code and the vehicle analysis code developed at ANL. The systems code includes models for the PEFC components and has been applied for steady-state and dynamic operations.

(2) The results of the steady-state analysis indicated that, at the design point, the system efficiency is above $50 \%$ for a $50-\mathrm{kW}$ system. The efficiency improves at partial load and approaches $60 \%$ at $40 \%$ load. The improvement results from the fuel cell operating at lower current densities on the V-I polarization curve. At much lower loads, the system efficiency drops because of the deterioration in the performance of the compressor and the expander. The system performance suffers at lower temperatures, as the characteristic polarization curve for the fuel cell shifts downward because of the increased ohmic losses.

(3) The results of the transient analysis indicated that the hydrogen-fueled PEFC system can start relatively rapidly, within seconds from ambient conditions. However, the warm-up time for this system is about $180 \mathrm{~s}$. It is important during this period for the coolant to bypass the system radiator until the coolant temperature approaches the design temperature for the fuel cell.

(4) The PEFC system has been evaluated for three mid-size vehicles: the 1995 Chrysler Sedan (LH), the near-term Ford AIV (Aluminum Intensive Vehicle) Sable, and the future P2000 vehicle. The results show that the PEFC system will respond well to the demands of the FUDS and Highway driving cycles, under both warm and cold starting conditions. The results also show that the 1995 Chrysler Sedan (LH) and the AIV Sable powered by the PEFC have impressive gains in fuel economy over that of the internal-combustion engine vehicle. However, these two vehicles will not be able to meet the PNGV goal of $80 \mathrm{mpg}$. On the other hand, the P2000 vehicle approaches this goal even with variable efficiency of the compressor and expander. It is expected to exceed that goal, by a comfortable margin, if the efficiency of the compressor and expander can be maintained constant (at $80 \%$ ) over the power range of the fuel cell system. 


\section{REFERENCES}

1. Kumar, R., Ahluwalia, R. K., Geyer, H. K., and Krumpelt, M., "Modeling of Polymer Electrolyte Fuel Cell Systems," Proceedings of the Annual Automotive Technology Development Contractor's Coordination Meeting, Society of Automotive Engineers, Inc., Warrendale, PA, P-278, pp. 409-417 (May 1994).

2. Geyer, H. K., Ahluwalia, R. K., and Kumar, R., "Dynamic Response of Steam-Reformed, Methane-Fueled Polymer Electrolyte Fuel Cell Systems," Proc. of $31^{\text {st }}$ Intersociety Energy Conservation Engineering Conference, Washington, DC, pp. 1101-1106 (August 11-16, 1996).

3. Srinivasan, S., Velev, O. A., Parthasarathy, A., Manko, D. J., and Appleby, A. J., "High Energy Efficiency and High Power Density Proton Exchange Membrane Fuel Cells Electrode Kinetics and Mass Transport," J. Power Sources, Vol. 36, pp. 299-320 (1991).

4. "Research and Development of Proton-Exchange (PEM) Fuel Cell System for Transportation Applications," Phase I, Final Report, DOE-CH/10435-02, Allison Gas Turbine Division, General Motors Corporation, Indianapolis, IN (January 1996).

5. "Direct-Hydrogen-Fueled Proton-Exchange-Membrane Fuel Cell System for Transportation Applications," Conceptual Design Report, DOE/CH50390-9, Pentastar Electronics, Inc., Huntsville, AL (March 1997).

6. "Direct-Hydrogen-Fueled Proton-Exchange-Membrane Fuel Cell System for Transportation Applications-Conceptual Vehicle Design Report, Pure Fuel Cell Powertrain Vehicle," DOE/CH/50389-501, Ford Motor Company, Dearborn, MI (February 1997).

\section{ACKNOWLEDGMENT}

This work was supported by the U. S. Department of Energy, Office of Advanced Automotive Technologies. 
Distribution for ANL-98/16

Internal:

R. K. Ahluwalia (10)

T. Q. Hua

S. Ahmed

L. R. Johnson

M. Krumpelt

R. Kumar (20)

S. K. Bhattacharyya

J. J. Laidler

E. D. Doss (10)

R. P. Larsen

P. J. Finck

J. F. Miller

K. M. Myles

V. J. Novick

W. F. Podolski

W. M. Swift

M. Q. Wang

H. K. Geyer

T. B. Yafe

G. L. Henriksen

TIS Files

External:

DOE-OSTI (2)

ANL-E Library

ANL-W Library

J. A. Adams, Ford Research Laboratory, Dearborn, MI

A. J. Appleby, Texas A\&M University, College Station, TX

B. Bates, Ford Motor Company, Dearborn, MI

R. Beeber, USCAR, Southfield, MI

J. M. Bentley, Arthur D. Little, Inc., Cambridge, MA

L. Blair, Los Alamos National Laboratory, Los Alamos, NM

C. Borroni-Bird, Chrysler Corporation, Madison Heights, MI

L. Cataquiz, USDOE, Office of Transportation Technologies, Washington, DC

S. G. Chalk, USDOE, Office of Transportation Technologies, Washington, DC

P. Davis, USDOE, Office of Transportation Technologies, Washington, DC

J. J. Eberhardt, USDOE, Office of Transportation Technologies, Washington, DC

W. D. Ernst, Plug Power L.L.C., Latham, NY

J. Ferrell, USDOE, Office of Transportation Technologies, Washington, DC

R. J. Fiskum, USDOE, Office of Building Energy Research, Washington, DC

M. H. Fronk, Delphi Energy and Engine Management Systems, West Henrietta, NY

J. Garbak, USDOE, Office of Transportation Technologies, Washington, DC

S. Gottesfeld, Los Alamos National Laboratory, Los Alamos, NM

P. G. Grimes, Patrick Grimes Associates, Westfield, NJ

S. Gronich, USDOE, Office of Solar Energy Conversion, Washington, DC

T. J. Gross, USDOE, Office of Transportation Technologies, Washington, DC

H. J. Hale, USDOE, Office of Transportation Technologies, Washington, DC

G. Halpert, Jet Propulsion Laboratory, Pasadena, CA

K. L. Heitner, USDOE, Office of Transportation Technologies, Washington, DC

D. L. Ho, USDOE, Office of Transportation Technologies, Washington, DC

P. R. Hoffmann, Hydrogen \& Fuel Cell Letter, Rhinecliff, NY

S. Q. Hsiung, DOT/FTA, Washington, DC

B. James, Directed Technologies, Inc., Arlington, VA

G. Joy, U.S. Department of Commerce, Washington, DC 
A. Kaufman, H-Power Corporation, Belleville, NJ

K. Kinoshita, Lawrence Berkeley Laboratory, Berkeley, CA

R. S. Kirk, USDOE, Office of Transportation Technologies, Washington, DC

R. A. Kost, USDOE, Office of Transportation Technologies, Washington, DC

J. Larkins, Georgetown Energy Programs, Washington, DC

J. Leonard, South Coast Air Quality Management District, Diamond Bar, CA

A. C. Lloyd, Desert Research Institute, Reno, NV

F. D. Lomax, Directed Technologies, Inc., Arlington, VA

T. Marechaux, USDOE, Office of Transportation Technologies, Washington, DC

A. P. Meyer, International Fuel Cells, South Windsor, CT

J. Milliken, USDOE, Office of Transportation Technologies, Washington, DC

F. Mitlitsky, Lawrence Livermore National Laboratory, Livermore, CA

R. J. Nowak, DARPA/DSO Defense Sciences Office, Arlington, VA

J. B. O'Sullivan, Electric Power Research Institute, Palo Alto, CA

J. M. Ohi, National Renewable Energy Laboratory, Golden, CO

P. G. Patil, USDOE, Office of Transportation Technologies, Washington, DC

P. D. Patterson, USDOE, Office of Transportation Technologies, Washington, DC

P. Prokopius, NASA Lewis Research Center, Cleveland, OH

T. Rehg, Allied-Signal, Torrance, CA

V. P. Roan, University of Florida, Palm Beach Gardens, FL

J. Romm, USDOE, Washington, DC

R. Rose, Fuel Cells 2000, Washington, DC

P. Rosenfeld, Chrysler Corporation, Auburn Hills, MI

R. Ross, Energy Partners, West Palm Beach, FL

N. Rossmeissl, USDOE, Washington, DC

J. Serfass, National Hydrogen Association, Washington, DC

G. D. Skellenger, GM Research and Environmental Staff, Warren, MI

C. Sloane, GM Research and Development Center, Warren, MI

A. J. Sobey, A. Sobey \& Associates, Bloomfield Hills, MI

R. Sutton, General Motors Research Laboratories, Warren, MI

S. Swathirajan, General Motors Research Laboratories, Warren, MI

W. P. Teagan, Arthur D. Little, Inc., Cambridge, MA

C. E. Thomas, Directed Technologies, Inc., Arlington, VA

K. A. Trimble, Gas Research Institute, Chicago, IL

D. Tudor, PEI Electronics, Huntsville, AL

N. E. Vanderborgh, Los Alamos National Laboratory, Los Alamos, NM

E. Wall, USDOE, Office of Transportation Technologies, Washington, DC

M. Warshay, NASA Lewis Research Center, Cleveland, $\mathrm{OH}$

D. Watkins, Los Alamos National Laboratory, Los Alamos, NM

R. White, University of South Carolina, Columbia, SC

B. Wilson, Sandia National Laboratories, Livermore, CA

$\mathrm{K}$. Winters, PEI Electronics, Huntsville, AL

K. Wipke, National Renewable Energy Laboratory, Golden, CO

R. E. York, General Motors Corporation, Warren, MI 